\title{
Genetic and morphological variation in corallivorous snails (Coralliophila spp.) living on different host corals at Curaçao, southern Caribbean
}

\author{
Gerrit Potkamp ${ }^{1,2}$, Mark J.A. Vermeij, ${ }^{2,3}$, Bert W. Hoeksema ${ }^{1,4,5}$ \\ ${ }^{1}$ Naturalis Biodiversity Center, PO Box 9517, 2300 RA Leiden, The Netherlands \\ ${ }^{2}$ Institute for Biodiversity and Ecosystem Dynamics, University of Amsterdam, PO Box 94248, 1090 GE Amsterdam, \\ The Netherlands \\ ${ }^{3}$ CARMABI Foundation, PO Box 2090, Piscaderabaai z/n, Willemstad, Curaçao \\ ${ }^{4}$ Institute of Biology Leiden, Leiden University, PO Box 9505, 2300 RA Leiden, The Netherlands \\ ${ }^{5}$ E-mail: bert.hoeksema@naturalis.nl
}

Key words: genetic differentiation; phylogenetics; 12S; COI; corallivory; morphology; geometric morphometrics; host race

urn:1sid:zoobank.org:pub:D375D61B-3EF8-4037-82FB-D25331D6D234

\begin{abstract}
Snails of the genus Coralliophila (Muricidae: Coralliophilinae) are common corallivores in the Caribbean, feeding on a wide range of host species. In the present study, the morphological and genetic variation in C. galea and C. caribaea were studied in relation to their association with host coral species at Curaçao. Differences in shell shape among snails living on different hosts were quantified using geometric morphometric and phylogenetic relationships were studied using two mitochondrial markers (12S and COI). Based on these analyses, a new species, C. curacaoensis sp. nov., was found in association with the scleractinian coral Madracis auretenra. Both C. galea and C. caribaea showed host-specific differences in shell shape, size, and shell allometry (i.e. changes in morphological development during growth). Shell spire variability contributed foremost to the overall variation in shell shape. In C. caribaea minor genetic differences existed between snails associated with scleractinian and alcyonacean corals, whereas in $C$. galea such intraspecific variation was not found. These results shed more light on morphological and genetic differences among coral-associated fauna living on different host species.
\end{abstract}

\section{Contents}

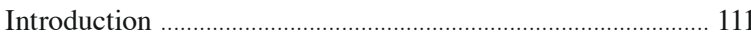

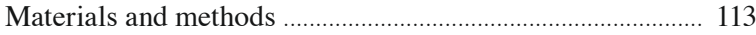

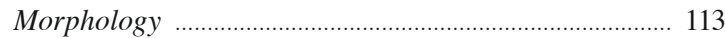

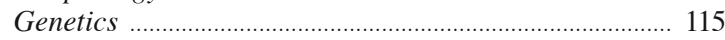

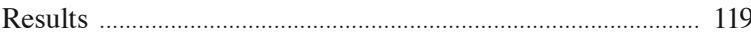

Shell dimensions ............................................................... 119

Shell shape ......................................................................... 119

Allometry ................................................................................. 125

Replication error in morphometric data ........................ 125

Sex ratios ......................................................................... 125

Genetics ............................................................................. 126

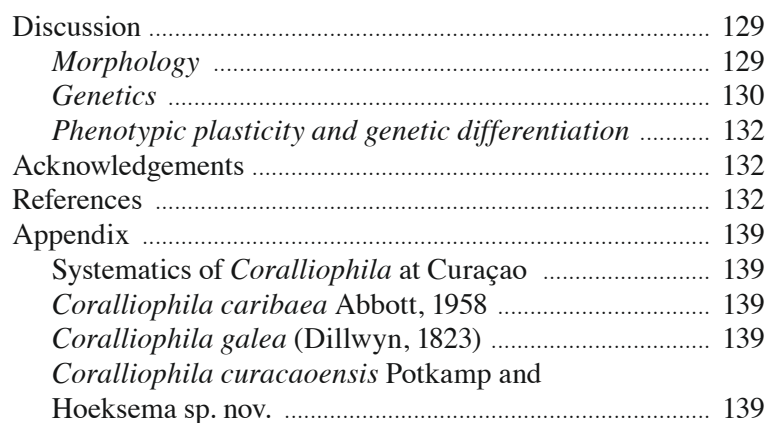

\section{Introduction}

Shallow tropical coral reefs are known as the world's most diverse marine ecosystems, with estimates of global species numbers ranging to over one million, constituting a large portion of marine species (ReakaKudla, 1997; Plaisance et al., 2011; Appeltans et al., 2012; Fisher et al., 2015). Many coral-associated species depend on their host for food, shelter or recruitment (Scott, 1987; Stella et al., 2010, 2011; Hoeksema et al., 2012, 2017). Currently, 51 invertebrates are known that feed on live scleractinian corals, of which 17 are obligate corallivores (Rotjan and Lewis 2008), while many other species prey on coral species other than scleractinians (Schiaparelli et al., 2005; Reijnen et al., 2010; Wolf et al., 2014; Sánchez et al., 2016). New cases of corallivory, involving new records of predator-prey combinations, are still being reported regularly (e.g., Berumen and Rotjan, 2010; Vermeij, 2010). 


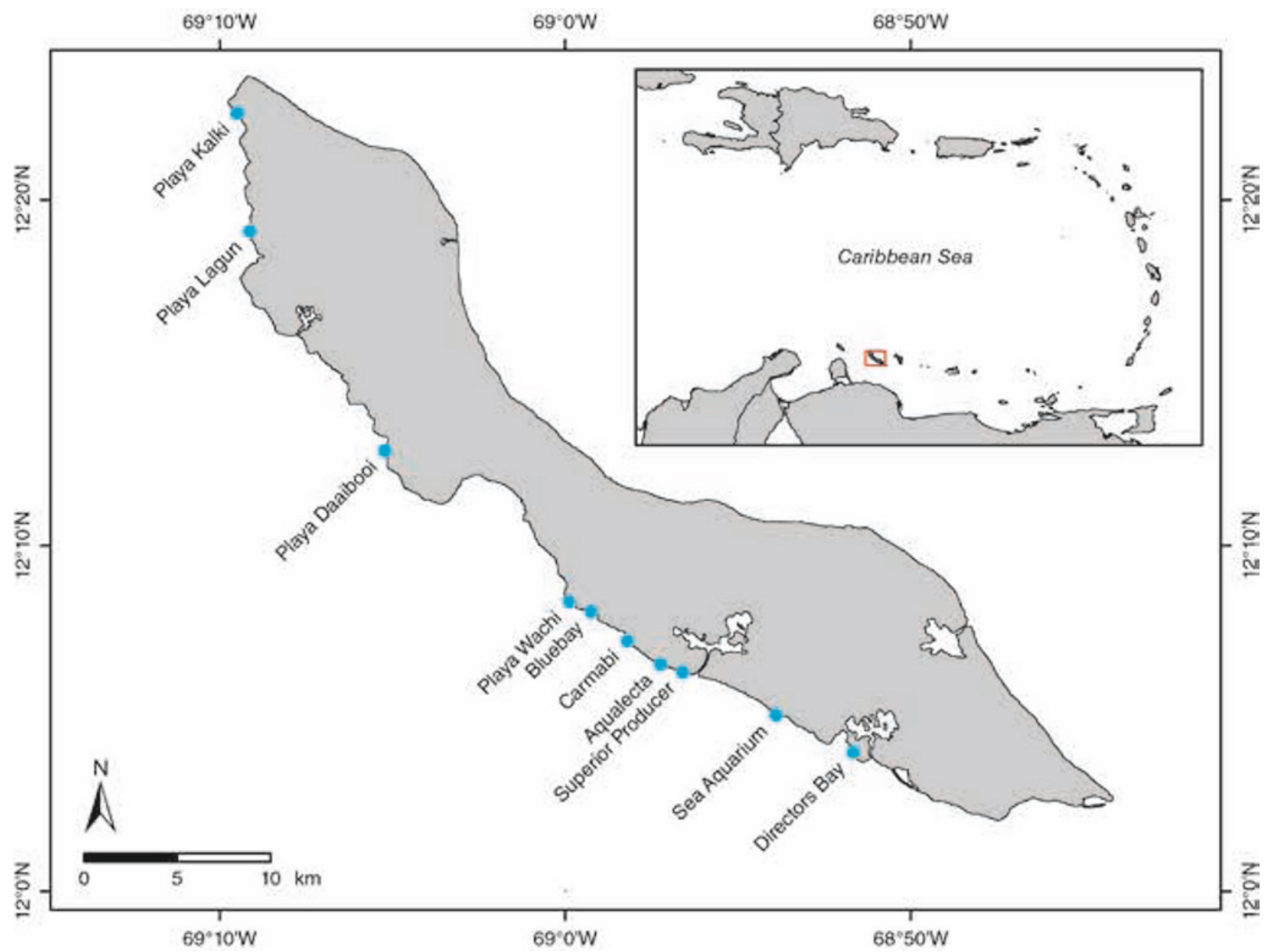

Fig. 1. Map of the localities along the coast of Curaçao where Coralliophila spp. were collected.

Snails belonging to the subfamily Coralliophilinae (Gastropoda: Muricidae), with 200-250 species described worldwide, are corallivores that feed on anthozoan host species (Oliverio and Mariottini, 2001a; Oliverio, 2008; Oliverio et al., 2009). Within this subfamily, species of the genus Coralliophila Adam and Adams, 1853 are common corallivores found on reefs in the Caribbean and Brazil, with C. galea (Dillwyn, 1823) and C. caribaea Abbott, 1958 as the most abundant species. These species associate with a wide range of anthozoan host species belonging to the hexacoral orders Scleractinia, Zoantharia or Coralliomorpharia, and/or the octocoral order Alcyonacea (Robertson, 1970; Miller, 1981; Dias and Gondim, 2016). Overlap in host species has been reported for C. galea and $C$. caribaea, involving hosts belonging to the Scleractinia, Zoantharia and Coralliomorpharia, but host partitioning has also been observed whereby C. carib- aea only preyed on alcyonaceans (Robertson, 1970; Miller, 1981), whereas $C$. galea preferred scleractinians (Miller, 1981).

In the ecological literature, the most common Coralliophila species in the Caribbean, C. galea, has often been misidentified as C. abbreviata (Lamarck, 1816) (see Bouchet, 2015; Netchy et al., 2016). Coralliophila abbreviata is a junior synonym of $C$. erosa (Röding, 1798), a species exclusively known from the Indo-Pacific (Oliverio, 2008). Predation by Coralliophila galea can negatively impact coral communities (Baums et al., 2003a). Bruckner et al. (1997), for example, measured a mean tissue consumption per snail of $1.9 \mathrm{~cm}^{2}$ day $^{-1}$, with a maximum of $6.5 \mathrm{~cm}^{2}$ day $^{-1}$ on Acropora palmata (Lamarck, 1816). C. galea predation also prevented the recovery of Acropora cervicornis (Lamarck, 1816) populations from damage caused by a hurricane (Knowlton et al. 1988, 1990). 
Host-specific differences in morphological and ecological traits may arise in both Coralliophila species, like host-related size structuring (Hayes, 1990a; Bruckner et al., 1997; Baums et al., 2003a; Johnston and Miller, 2006, Johnston et al., 2012) and timing of sex change in $C$. galea (Baums et al., 2003a; Johnston and Miller, 2006). Host-associated cryptic species also occur among coral-associated gastropods in the IndoPacific. Gittenberger and Gittenberger (2011) reported on an adaptive, host-associated radiation among endolithic snails of the genus Leptoconchus Rüppell, 1834 (Coralliophilinae), consisting of 14 cryptic species living inside the skeletons of 24 species of mushroom coral hosts (Scleractinia: Fungiidae). A similar adaptive radiation was found among 22 snails of the family Epitoniidae divided over 34 host coral species (Gittenberger and Gittenberger, 2005; Gittenberger and Hoeksema, 2013). In C. galea, only a weak genetic divergence existed between snails associated with the scleractinians Acropora palmata and Orbicella spp. (Johnston et al., 2012).

In the present study, host-specific differences in size, shell shape and allometric patterns as well as genetic differences in both C. galea and C. caribaea were found in response to living of different scleractinian and alcyonacean host species. To study shell morphology independent of shell size, landmarkbased geometric morphometrics were used to model shell shape (see e.g., Stone, 1998; Carvajal-Rodríguez et al., 2005; Queiroga et al., 2011; Mariani et al., 2012; Burridge et al., 2015; Liew and Schilthuizen, 2016). Host-related size structuring has been observed for C. galea, and was consequently also expected for $C$. caribaea in addition to host-associated differences in shell shape and allometry.

Two mitochondrial markers (12S rRNA and cytochrome $c$ oxidase subunit I) were used to assess intraspecific host-associated genetic divergence in $C$. galea and C. caribaea across the whole range of their host species at Curaçao, extending the results of Johnston et al. (2012). Based on Johnston et al. (2012), who found high gene flow across the Caribbean and weak host-associated divergence within $C$. galea, we expect genetic divergence among host species to be low or absent for both C. galea and C. caribaea. By combining morphological and genetic methods, additional information has been obtained regarding the evolutionary and ecological relations between corallivorous snails and their hosts. Lastly, a new species, C. curacaoensis Potkamp and Hoeksema sp. nov., was found and described (see Appendix).

\section{Materials and methods}

Snails were collected in January-March 2015 from coral colonies at ten localities along the leeward coast of Curaçao, southern Caribbean (Fig. 1). Colonies of scleractinians and alcyonaceans were haphazardly selected and searched for snails during SCUBA dives. As the sampling effort was not equal among localities and localities were $<50 \mathrm{~km}$ apart from each other, locality was not used as a factor in statistical analyses. Aforementioned surveys of invertebrates associated with corals appear to be effective, as they have previously resulted in new host records for Curaçao and the Caribbean in for example ovulid snails on octocorals (Reijnen et al., 2010), gall crabs in scleractinians (Van der Meij, 2014) and serpulids in reef corals (Hoeksema et al., 2015; Hoeksema and Ten Hove, 2017).

All snails associated with a colony were collected and stored in one plastic sampling bag per host colony. Host corals were photographed and their identity, depth and locality were recorded. If present, feeding scars were photographed as well. After sampling, snails were put in $96 \%$ ethanol (in a few cases $70 \%$ ethanol) until further processing. All specimens have been deposited in the collections of Naturalis Biodiversity Center, Leiden, the Netherlands (catalogued under numbers coded $\mathrm{RMNH}$ ). In the case of snails associated with alcyonaceans, a small sample of the distal part of host colonies was also collected for species identification. Alcyonacean sclerites were isolated by dissolving the coenchymal tissue in sodium hypochlorite (4\% household bleach solution). Alcyonaceans were identified to the genus level using photographs and light microscopy slides of the sclerites, using the keys by Bayer (1961).

\section{Morphology}

Shell length of the snails was measured with a digital calliper to the nearest $0.01 \mathrm{~mm}$. Of 60 snails $(7 \%$ of total), only the shell length was measured with a Vernier calliper to the nearest $0.05 \mathrm{~mm}$. Shell length was defined as the length from the tip of the apex to the tip of the aperture (end of the anterior canal) (Fig. 2). To determine any measurement error that could arise from inconsistencies in the orientation of the shell between the calliper blades, the shell length of 65 snails was measured in triplicate. The measurement error was defined as the average distance to the mean of the three replicate measurements of each shell. The error for shells measured with the Vernier calliper was not calculated. Shell lengths and widths were log-transformed 


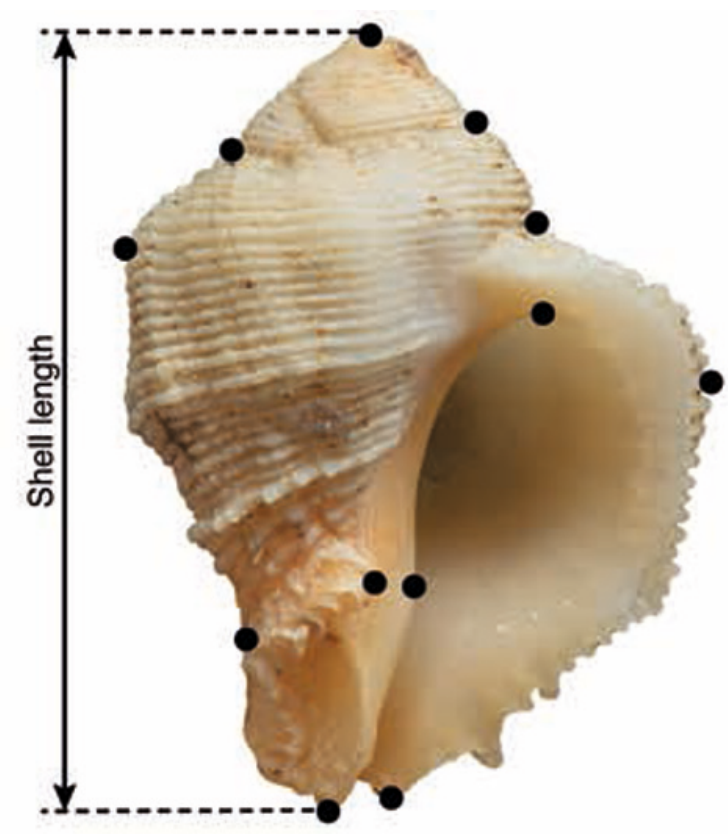

Fig. 2. Shell length as used to measure all shells. Twelve black points represent the 12 landmarks used in the geometric morphometric analysis.

in all statistical analysis to achieve normal distributions and homogeneity of variance. Differences in shell length were tested using ANOVA models and in some cases using Kruskall-Wallis rank sum tests.

Landmark-based geometric morphometrics were used to assess the shape of each shell. After measuring shell length, the ventral side (aperture facing upwards) was photographed with a Nikon D7000 DSLR camera equipped with a Sigma $105 \mathrm{~mm}$ macro lens. The locations of 12 landmarks were recorded on each photo (Fig. 2) and chosen to capture the observed variation in shell shape during shell measurements. Most of these landmarks have been used before in the morphometrics of gastropods (Zelditch et al., 2004; Hollander et al., 2006; Mariani et al., 2012). Shells covered by encrusting algae were excluded from this analysis because their landmarks were hidden. To align landmarks and remove the effect of size, a generalized Procrustes superimposition was applied to the data (Gower, 1975; Rohlf and Slice, 1990). Replication errors landmark data were calculated as well. See Online Supplementary Material 1 for the methods followed.

To statistically test for differences in shell shape and potential relationships between shell shape and shell size, snail host species or depth (as well as the interactions between host species and both shell size and depth), distance-based Procrustes ANOVA models were used that are equivalent to other distance-based ANOVA methods, like PerMANOVA (Goodall 1991; Anderson 2001; Adams and Otárola-Castillo 2013). For all Procrustes ANOVA models, significance of the different factors was tested against 10,000 permutations. Host-associated differences in shell shape were tested through pairwise comparisons of the effect of host species in a full model (with all tested factors included) against a reduced model (with all factors except host species included). To account for multiple tests, $p$ values were corrected using a Bonferroni correction.

To define allometric patterns, a common allometric component (CAC) was calculated from the landmark data to express allometric patterns as one variable (Mitteroecker et al., 2004). Host-specific regressions between CAC and shell length were made (excluding hosts having less than five specimens with morphometric data). The vectors of shell length of snails associated with different host species were compared to reveal differences in allometric patterns in the amount of change in shell shape per unit of growth (corresponding to the distance among vectors of shell length) and the direction of shell shape change (corresponding to the correlation among vectors of shell length). Pairwise comparisons of both the distance and correlation among the vectors of shell length were made between a full model and a reduced model without the interaction between the factors host species and shell length (see Online Supplementary Material 2). As before, the $p$ values were corrected with a Bonferroni correction.

To visualize variation in shell shape, a principal component analysis (PCA) was performed using the landmark data. To separate real variation in shell shape from noise resulting from the error described above and calculate repeatability of axes, landmark data of the three replicated photos was included in the PCA. Intraclass correlation coefficients (ICC, model 2,1) were calculated between the PCA-scores of triplicates on all PCA-axes. An axis was considered repeatable when the ICC was higher than 0.80 (Burridge et al., 2015). To visualize differences in allometric patterns among snails associated with different host species, linear regressions between PCA scores and shell length were used to predict PCA scores (and therefore shell shape) of shells of specific lengths associated with specific host species

After the morphometric analysis, shells were crushed to remove the snail from its shell. Using a dissecting microscope, the sex of each snail was determined by presence or absence of a penis just above the left eye- 
Table 1. Sequences of forward (F) and reverse (R) primers for the amplification of two mitochondrial markers, 12S rRNA (12S) and cytochrome $c$ oxidase subunit I (COI). All primers are as in Barco et al. (2010).

\begin{tabular}{llll}
\hline Marker & Primer & Sequence (5'-3') & Reference \\
\hline \multirow{2}{*}{ 12S } & 12S-I (F) & TGC CAG CAG YCG CGG TTA & Oliverio and Mariottini (2001) \\
& 12S(-) (R) & AGA GYG RCG GGC GAT GTG T & Bandyopadhyay et al. (2008) \\
COI & LCO1490 (F) & GGT CAA CAA ATC ATA AAG ATA TTG G & Folmer et al. (1994) \\
& HC02198 (R) & TTA ACT TCA GGG TGA CCA AAA AAT CA & Modified from Folmer et al. (1994) \\
\hline
\end{tabular}

a: $\mathrm{R}=\mathrm{A}, \mathrm{G} ; \mathrm{Y}=\mathrm{C}, \mathrm{T}$

stalk. Differences in sex ratios among snails associated with different host species were assessed using Fisher's exact tests. For tests on larger tables (to test for differences among host species), $p$-values were computed using Monte Carlo simulations, with 1 million replications. Pairwise differences among host species were assessed using pairwise Fisher's exact tests; $p$-values were corrected using a Bonferroni correction. Linear regressions were made between sex ratio and mean shell length, and between mean male and female shell length. Individual points (corresponding to a single host species) were weighed according to the number of specimens. Only host species with more than five specimens were included in the analyses comparing snails among host species.

All statistics were done in R, using the package Geomorph 2.1.5 for all morphometric analyses (Adams and Otárola-Castillo, 2013; Adams et al., 2015; R Core Team, 2015).

\section{Genetics}

A small piece of tissue was removed from the foot of a selection of snails for genetic analysis. Two mitochondrial markers were amplified and sequenced: a fragment the 12S rRNA (12S) gene and a fragment of the cytochrome $c$ oxidase subunit 1 gene (COI). Both markers have been used extensively and proven informative in closely related gastropods (Oliverio and Mariottini, 2001a, 2001b; Barco et al., 2010; Gittenberger and Gittenberger, 2011). DNA was extracted on a KingFisher Flex magnetic particle processor (Thermo Scientific), using the Nucleospin Tissue kit (Macherey-Nagel, Düren, Germany). PCR reaction mixtures consisted for both markers of $0.25 \mu \mathrm{L}$ QIAGEN Taq DNA polymerase (5 units $\left.\mu \mathrm{L}^{-1}\right), 0.5 \mu \mathrm{L}$ dNTPs $(2.5 \mathrm{mM})$ and $1.0 \mu \mathrm{L}$ of both the forward and reverse primers, as well as 0.5 $\mu \mathrm{L} 100 \mathrm{mM}$ Promega BSA, $0.5 \mu \mathrm{L} 25 \mathrm{mM} \mathrm{MgCl}, 2.5$ $\mu \mathrm{L}$ 10x PCR buffer (QIAGEN) and $15.8 \mu \mathrm{L}$ milli-Q water. In the PCR, an annealing temperature of $50^{\circ} \mathrm{C}$ was used for both $12 \mathrm{~S}$ and COI. PCR products were sequenced using Sanger sequencing by BaseClear (Leiden, the Netherlands). Primers were used as in Barco et al. (2010) (Table 1). Five previously published sequences were used in the phylogenetic analysis (Table 2).

Forward and reverse sequences were assembled automatically and edited by hand in Sequencher 5.4 (Gene Codes Corporation, Ann Arbor, MI, USA). Sequences were aligned using the MAFFT algorithm on the GUIDANCE2 server (Katoh et al., 2005; Sela et al., 2015). The appropriate substitution model for either marker was determined based on the Akaike information criterion (AIC) in both the jModelTest 2.1.7 and MrModeltest 2 software packages (Nylander, 2004; Darriba et al., 2012). Both software packages agreed on the best substitution model to be used in MrBayes. The GTR $+\Gamma$ (Tavaré 1986) model was used for $12 \mathrm{~S}$, the HKY85 + $\Gamma+$ I (Hasegawa et al., 1985) model was used for COI. A phylogenetic tree was constructed based on both markers separately as well as a concatenated dataset using Bayesian inference with the (parallel) Metropolis coupled Markov chain Monte Carlo $\left((\mathrm{MC})^{3}\right)$ method in MrBayes 3.2 (Altekar et al., 2004; Ronquist et al., 2012). In MrBayes, the (MC) ${ }^{3}$ analysis was run in duplicate, for a length of 25,000,000 generations for the concatenated dataset and a length of $15,000,000$ generation for the trees based on single markers. Trees were sampled every 100 generations. Burn-in was determined by looking at the deviation of split frequencies, trees sampled before this deviation dropped below 0.01 were discarded. For the concatenated analysis, the burn-in was determined to be 1.49 million generations, almost $6 \%$ of the total length of the analysis. For the trees based on $12 \mathrm{~S}$ and COI separately, burn-in was determined to be 555,000 and $1,155,000$ generations respectively. Sequences of the muricid species Drupella rugosa (Born, 1778), previously published by Claremont et al. (2011), were used as an outgroup. 
Table 2. Specimens used in phylogenetic analysis with their voucher numbers (RMNH) and GenBank accession numbers.

\begin{tabular}{|c|c|c|c|}
\hline \multirow[b]{2}{*}{ Species / Host taxon } & \multirow[b]{2}{*}{ Voucher } & \multicolumn{2}{|c|}{ Accession numbers } \\
\hline & & $12 S$ & COI \\
\hline \multicolumn{4}{|l|}{ Coralliophila galea (Dillwyn, 1823) } \\
\hline \multicolumn{4}{|l|}{ Host: Subclass Hexacorallia, Order Scleractinia } \\
\hline Acroporidae & & & \\
\hline \multirow[t]{3}{*}{ Acropora palmata (Lamarck, 1816) } & RMNH.5004294 & KY829357 & KY818778 \\
\hline & RMNH.5004295 & - & KY818777 \\
\hline & RMNH.5004296 & - & KY818776 \\
\hline \multicolumn{4}{|l|}{ Agariciidae } \\
\hline \multirow[t]{3}{*}{ Agaricia agaricites (Linnaeus, 1758) } & RMNH.5004297 & KY829360 & KY818784 \\
\hline & RMNH.5004298 & KY829359 & KY818783 \\
\hline & RMNH.5004299 & - & KY818782 \\
\hline Agaricia humilis Verrill, 1901 & RMNH.5004300 & - & KY818781 \\
\hline \multirow{2}{*}{ Agaricia lamarcki Milne Edwards and Haime, 1851} & RMNH.5004301 & - & KY818780 \\
\hline & RMNH.5004302 & KY829358 & KY818779 \\
\hline \multicolumn{4}{|l|}{ Astrocoeniidae } \\
\hline \multirow{3}{*}{ Madracis auretenra Locke, Weil and Coates, 2007} & RMNH.5004306 & KY829354 & KY818772 \\
\hline & RMNH.5004307 & KY829353 & KY818771 \\
\hline & RMNH.5004308 & KY829352 & KY818770 \\
\hline \multicolumn{4}{|l|}{ Meandrinidae } \\
\hline \multirow[t]{2}{*}{ Meandrina meandrites (Linnaeus, 1758) } & RMNH.5004309 & KY829350 & KY818768 \\
\hline & RMNH.5004310 & KY829349 & KY818767 \\
\hline \multicolumn{4}{|l|}{ Merulinidae } \\
\hline \multirow[t]{3}{*}{ Orbicella annularis (Ellis and Solander, 1786) } & RMNH.5004312 & KY829348 & KY818766 \\
\hline & RMNH.5004313 & KY829347 & KY818765 \\
\hline & RMNH.5004314 & KY829346 & KY818764 \\
\hline \multirow[t]{2}{*}{ Orbicella faveolata (Ellis and Solander, 1786) } & RMNH.5004315 & KY829345 & KY818763 \\
\hline & RMNH.5004316 & KY829344 & KY818762 \\
\hline \multirow{2}{*}{ Orbicella franksi (Gregory, 1895) } & RMNH.5004317 & KY829343 & KY818761 \\
\hline & RMNH.5004318 & KY829342 & KY 818760 \\
\hline \multicolumn{4}{|l|}{ Montastraeidae } \\
\hline Montastraea cavernosa (Linnaeus, 1767) & RMNH.5004311 & KY829351 & KY818769 \\
\hline \multicolumn{4}{|l|}{ Mussidae } \\
\hline Colpophyllia natans (Houttuyn, 1772) & RMNH.5004303 & - & KY818775 \\
\hline \multirow{2}{*}{ Diploria labyrinthiformis (Linnaeus, 1758) } & RMNH.5004304 & KY829356 & KY818774 \\
\hline & RMNH.5004305 & KY829355 & KY818773 \\
\hline \multirow[t]{2}{*}{ Pseudodiploria clivosa (Ellis and Solander, 1786) } & RMNH.5004320 & - & KY818759 \\
\hline & RMNH.5004321 & - & KY818786 \\
\hline Pseudodiploria strigosa (Dana, 1846) & RMNH.5004322 & KY829361 & - \\
\hline \multicolumn{4}{|l|}{ Poritidae } \\
\hline Porites porites (Pallas, 1766) & RMNH.5004319 & - & KY818785 \\
\hline
\end{tabular}

\section{Coralliophila caribaea Abbott, 1958}

Host: Subclass Hexacorallia, Order Scleractinia

Agariciidae

Agaricia lamarcki Milne Edwards and Haime, 1851

Meandrinidae

Meandrina meandrites (Linnaeus, 1758)

Montastraeidae

Montastraea cavernosa (Linnaeus, 1767)

Mussidae

Colpophyllia natans (Houttuyn, 1772)

Diploria labyrinthiformis (Linnaeus, 1758)

Mycetophyllia ferox Wells, 1973

Pseudodiploria strigosa (Dana, 1846)

$\begin{array}{lll}\text { RMNH.5004274 } & - & \text { KY818724 } \\ \text { RMNH.5004278 } & \text { KY829309 } & - \\ & & \\ \text { RMNH.5004279 } & \text { KY829323 } & \text { KY818739 } \\ \text { RMNH.5004280 } & \text { KY829322 } & \text { KY818738 } \\ \text { RMNH.5004281 } & \text { KY829321 } & \text { KY818737 } \\ & & \\ \text { RMNH.5004275 } & \text { KY829310 } & - \\ \text { RMNH.5004276 } & - & \text { KY818755 } \\ \text { RMNH.5004277 } & \text { KY829338 } & \text { KY818754 } \\ \text { RMNH.5004282 } & \text { KY829320 } & \text { KY818736 } \\ \text { RMNH.5004290 } & - & \text { KY818728 }\end{array}$


Accession numbers

\begin{tabular}{|c|c|c|c|}
\hline Species / Host taxon & & Voucher & 12SCOI \\
\hline \multicolumn{4}{|l|}{ Poritidae } \\
\hline \multirow[t]{3}{*}{ Porites astreoides Lamarck, 1816} & RMNH.5004283 & - & KY818735 \\
\hline & RMNH.5004284 & KY829319 & KY818734 \\
\hline & RMNH.5004285 & KY829318 & KY818733 \\
\hline \multirow[t]{4}{*}{ Porites porites (Pallas, 1766) } & RMNH.5004286 & KY829316 & KY818731 \\
\hline & RMNH.5004287 & KY829315 & KY818730 \\
\hline & RMNH.5004288 & KY829314 & KY818729 \\
\hline & RMNH.5004289 & KY829317 & KY818732 \\
\hline \multicolumn{4}{|l|}{ Siderastreidae } \\
\hline \multirow{3}{*}{ Siderastrea siderea (Ellis and Solander, 1768) } & RMNH.5004291 & KY829313 & KY818727 \\
\hline & RMNH.5004292 & KY829312 & KY818726 \\
\hline & RMNH.5004293 & KY829311 & KY818725 \\
\hline \multicolumn{4}{|l|}{$\begin{array}{l}\text { Host: Subclass Octocorallia, Order Alcyonacea } \\
\text { Gorgoniidae }\end{array}$} \\
\hline \multirow[t]{5}{*}{ Antillogorgia sp. } & RMNH.5004260 & KY829336 & KY818752 \\
\hline & RMNH.5004261 & KY829334 & KY 818750 \\
\hline & RMNH.5004262 & KY829332 & KY818748 \\
\hline & RMNH.5004263 & KY829331 & KY818747 \\
\hline & RMNH.5004264 & KY829325 & KY818741 \\
\hline Gorgonia sp. & RMNH.5004268 & KY829337 & KY818753 \\
\hline \multicolumn{4}{|l|}{ Plexauridae } \\
\hline \multirow[t]{3}{*}{ Eunicea sp. } & RMNH.5004265 & KY829333 & KY818749 \\
\hline & RMNH.5004266 & KY829327 & KY818743 \\
\hline & RMNH.5004267 & KY829324 & KY818740 \\
\hline \multirow[t]{5}{*}{ Pseudoplexaura sp. } & RMNH.5004269 & KY829335 & KY818751 \\
\hline & RMNH.5004270 & KY829330 & KY818746 \\
\hline & RMNH.5004271 & KY829329 & KY818745 \\
\hline & RMNH.5004272 & KY829328 & KY818744 \\
\hline & RMNH.5004273 & KY829326 & KY 818742 \\
\hline
\end{tabular}

\section{Coralliophila curacaoensis Potkamp and Hoeksema sp. nov.}

Host: Subclass Hexacorallia, Order Scleractinia

Astrocoeniidae

Madracis auretenra Locke, Weil and Coates, 2007

RMNH.5004323

RMNH.5004324

RMNH.5004325
KY829340 KY829339 KY829341
KY818757 KY818756 KY818758

\section{Coralliophila fontanangioyae Smriglio and Mariottini, 2000}

Host: Subclass Hexacorallia, Order Scleractinia

Astrocoeniidae

Madracis asperula Milne Edwards and Haime, 1849

- $\quad$ FN391972

\section{Coralliophila meyendorffii (Calcara, 1845)}

Host: Subclass Hexacorallia, Order Scleractinia

Dendrophylliidae Balanophyllia europaea (Risso, 1826)

- $\quad$ AJ297519 ${ }^{\mathrm{b} ; \mathrm{c}} \quad$ FN651936 $^{\mathrm{c}}$

Coralliophila mira (Cotton and Godfrey, 1932)

-

-

FN651853c

FN651937

Leptoconchus sp.

-

$-$

FN391979

FN651939

Drupella rugosa (Born, 1778)

$-$

$-$

FR854011

FR853848d

Previously published sequenches: ${ }^{\mathrm{a}}$ Oliverio et al. (2009); ${ }^{\mathrm{b}}$ Oliverio and Mariottini (2001); ${ }^{\mathrm{c}}$ Barco et al. (2010); ${ }^{\mathrm{d}}$ Claremont et al. (2011). 
Table 3. Number of specimens of Coralliophila spp. collected from different hosts species (C) and the number of specimens used in the morphometric analyses (M). Numbers between brackets indicate the number of host colonies from which snails were collected.

\begin{tabular}{|c|c|c|c|c|c|c|}
\hline \multirow[b]{2}{*}{ Host species } & \multicolumn{2}{|c|}{$\begin{array}{l}\text { Coralliophila } \\
\text { galea }\end{array}$} & \multicolumn{2}{|c|}{$\begin{array}{l}\text { Coralliophila } \\
\text { caribaea }\end{array}$} & \multicolumn{2}{|c|}{$\begin{array}{l}\text { Coralliophila } \\
\text { curacaoensis } \\
\text { sp. nov. }\end{array}$} \\
\hline & $\mathbf{C}$ & $\mathbf{M}$ & $\mathbf{C}$ & $\mathbf{M}$ & $\mathbf{C}$ & $\mathbf{M}$ \\
\hline \multicolumn{7}{|l|}{ Subclass Hexacorallia, Order Scleractinia } \\
\hline Acropora palmata (Lamarck, 1816) & $7(3)$ & 4 & & & & \\
\hline \multicolumn{7}{|l|}{ Agariciidae } \\
\hline Agaricia agaricites (Linnaeus, 1758) & $66(12)$ & 59 & & & & \\
\hline Agaricia humilis Verrill, 1901 & $49(17)$ & 29 & & & & \\
\hline Agaricia lamarcki Milne Edwards and Haime, 1851 & $24(7)$ & 20 & $3(3)$ & - & & \\
\hline \multicolumn{7}{|l|}{ Astrocoeniidae } \\
\hline Madracis auretenra Locke, Weil and Coates, 2007 & $8(2)$ & - & & & $10(3)$ & 7 \\
\hline \multicolumn{7}{|l|}{ Meandrinidae } \\
\hline Meandrina meandrites (Linnaeus, 1758) & $55(8)$ & 39 & $5(3)$ & 1 & & \\
\hline \multicolumn{7}{|l|}{ Merulinidae } \\
\hline Orbicella annularis (Ellis and Solander, 1786) & $224(29)$ & 138 & & & & \\
\hline Orbicella faveolata (Ellis and Solander, 1786) & $55(9)$ & 32 & & & & \\
\hline Orbicella franksi (Gregory, 1895) & $22(5)$ & 15 & & & & \\
\hline \multicolumn{7}{|l|}{ Montastraeidae } \\
\hline Montastraea cavernosa (Linnaeus, 1767) & $1(1)$ & - & $5(2)$ & 2 & & \\
\hline \multicolumn{7}{|l|}{ Mussidae } \\
\hline Colpophyllia natans (Houttuyn, 1772) & $34(11)$ & 20 & $7(5)$ & 4 & & \\
\hline Diploria labyrinthiformis (Linnaeus, 1758) & $29(10)$ & 16 & $1(1)$ & - & & \\
\hline Mycetophyllia ferox Wells, 1973 & & & $1(1)$ & - & & \\
\hline Pseudodiploria clivosa (Ellis and Solander, 1786) & $7(2)$ & 2 & & & & \\
\hline Pseudodiploria strigosa (Dana, 1846) & $107(12)$ & 68 & $3(3)$ & - & & \\
\hline \multicolumn{7}{|l|}{ Poritidae } \\
\hline Porites astreoides Lamarck, 1816 & & & $7(3)$ & 4 & & \\
\hline Porites divaricata Le Sueur, 1820 & & & $1(1)$ & - & & \\
\hline Porites furcata Lamarck, 1816 & & & $3(2)$ & 1 & & \\
\hline Porites porites (Pallas, 1766) & $1(1)$ & - & $18(6)$ & 8 & & \\
\hline \multicolumn{7}{|l|}{ Siderastreidae } \\
\hline Siderastrea siderea (Ellis and Solander, 1768) & $1(1)$ & - & $27(6)$ & 21 & & \\
\hline \multicolumn{7}{|l|}{ Subclass Octocorallia, Order Alcyonacea } \\
\hline Antillogorgia sp. & & & $16(7)$ & 3 & & \\
\hline Gorgonia sp. & & & $5(3)$ & - & & \\
\hline \multicolumn{7}{|l|}{ Plexauridae } \\
\hline Eunicea sp. & & & $13(5)$ & 2 & & \\
\hline Plexaura sp. & & & $2(1)$ & - & & \\
\hline Pseudoplexaura sp. & & & $22(6)$ & 9 & & \\
\hline
\end{tabular}

Finally, an automatic barcode gap discovery analysis (ABGD) based on Kimura two-parameter (K2P) model on the marker COI was used to assess species delineation on the phylogenetic tree and to identify Molecular Operational Taxonomic Units (MOTUs) (see Kimura, 1980; Blaxter, 2004; Puillandre et al., 2012; Barco et al., 2013). Sequences from coralliophiline snails previously published by Harasewych et al.
(1997), Puillandre et al. (2009), Barco et al. (2010), Claremont et al. (2011) and Gittenberger and Gittenberger (2011) were included in this analysis (Online Supplementary Material 3), while the outgroup was excluded.

To further assess host-associated genetic divergence, a haplotype network was built for both $C$. galea and $C$. caribaea, using both markers separately. Networks were calculated using an infinite site model based on uncor- 
rected distances between haplotypes. To statistically assess intraspecific genetic divergence, an AMOVA ( $p$ values calculated based on 100,000 permutations) with host species or host order for both C. galea and C. caribaea was used on both markers. Statistics on genetic data and the calculation of the haplotype networks were performed in R using the packages APE 3.4 and pegas 0.8-2 (Paradis et al., 2004; Paradis, 2010; R Core Team, 2015).

\section{Results}

Across all sampled localities along the coast of Curaçao, a total of $>500$ colonies of Scleractinia and $>$ 70 colonies of Alcyonacea were searched for snails. Three species of Coralliophila were found associated with either Scleractinia or Alcyonacea. Besides $C$. galea and C. caribaea, a new species, $C$. curacaoensis Potkamp and Hoeksema sp. nov. was found (described in Appendix).

A total of 690 specimens of C. galea, 139 specimens of C. caribaea and 10 specimens of C.curacaoensis sp. nov. were found on a total of 157 scleractinian colonies and 22 gorgonians (Table 3; voucher numbers RMNH.5004260-5004370). Coralliophila caribaea occurred on both host species groups, whereas the other two Coralliophila species were only found on scleractinians. In 10 out of 157 associations, C. galea co-existed on the same host colony with either $C$. caribaea or C. curacaoensis sp. nov. (on two colonies). Coralliophila snails were found in association with 20 host species in total, belonging to ten scleractinian genera (Table 3): C. galea occurred on 16 hosts species (Fig. 3), C. caribaea on 12 hosts species (Fig. 4), and C. curacaoensis sp. nov. on a single host species (Fig. 5). In addition, $C$. caribaea occurred on five alcyonacean taxa (Fig. 4). Coralliophila galea and C. caribaea shared seven host species, whereas $C$. curacaoensis sp. nov. shared its single host species, Madracis auretenra Locke, Weil and Coates, 2007, with C. galea (Table 3).

In case of scleractinian hosts, both $C$. galea and $C$. caribaea were usually found at the edge of living coral tissue. On corals with a massive or plate-like growth form, snails were usually found at or underneath the edge of their host (Figs. 3d-e; 3h-i; 3k; 4a; 4d-e). Some snails occurred inside crevices and in between ridges of the host colony, in case of for example C. galea on Pseudodiploria strigosa (Dana, 1846) (Fig. 31) and C. caribaea on Siderastrea siderea (Ellis and Solander, 1768) (Fig. 4g). On large coral colonies of Orbicella annularis (Ellis and Solander, 1786), C. galea commonly clustered together in groups in crevices between the columns that make up the host colonies, again at the edge of living coral tissue (Fig. 3f). Snails on branching corals were found on the branches themselves, such as C. curacaoensis sp. nov. on M. auretenra (Figs. 3g; 3j; 4b-c; 5).

Snails on alcyonacean hosts were usually found at the base of the colonies (Fig. 4h) but also on the branches, usually on a dead patch (Fig. 4f). Some snails situated underneath the edge of the coral base were almost endofaunal (Figs. 4i-k). Snails sometimes occurred in small aggregations, tightly stacked on top of each other (Figs. 4i-j). Predation on host colonies was visible as damage to the soft surface tissue or its complete removal, leaving bare skeleton behind (Fig. 6). Damage on coral tissue seemed minimal for most host species, despite the occurrence of snail aggregations, except for a few host colonies showing more severe damage (e.g., Fig. 3a). In absence of long-term monitoring of coral colonies, it was unclear whether such damage is indeed the result of predation by Coralliophila spp. or if it was already present when the snails arrived.

\section{Shell dimensions}

Shell length of $C$. galea and $C$. caribaea ranged from 3.4 to $38.9 \mathrm{~mm}$ and 4.3 to $25.8 \mathrm{~mm}$ respectively. In both species, a clear host-associated size structuring of shell length existed $(\mathrm{F}=13.6 ; p<0.0001$ and $\mathrm{F}=5.8$; $p<0.0001$ for $C$. galea and C. caribaea, respectively (Fig. 7). The mean length of $C$. galea, snails differed among host species (29 combinations of host pairs, post-hoc Tukey HSD test), compared to a total of for $C$. caribaea (Tables S2-S3 in Online Supplementary Material 4). C. caribaea (nine pairs of hosts) associated with alcyonacean host species that were larger (based on shell length) than snails associated with scleractinian hosts (including all specimens; $\mathrm{F}=23.8 ; p<$ 0.0001; Fig. 7).

C. curacaoensis sp. nov. was on average smaller (shell length 2.5-8.9 mm) than C. galea and C. caribaea. However, C. curacaoensis sp. nov. was only found on Madracis auretenra, which was also a host of $C$. galea. Coralliophila galea individuals associated with M. auretenra (shell length 5.4-9.7 $\mathrm{mm}$ ) were not different in size compared to specimens of $C$. curacaoensis sp. nov. $(\mathrm{F}=4.07 ; p=0.061)$.

\section{Shell shape}

Landmarks could be recorded from a total of 504 out of 631 photographed specimens $(60.1 \%$ of all collected 

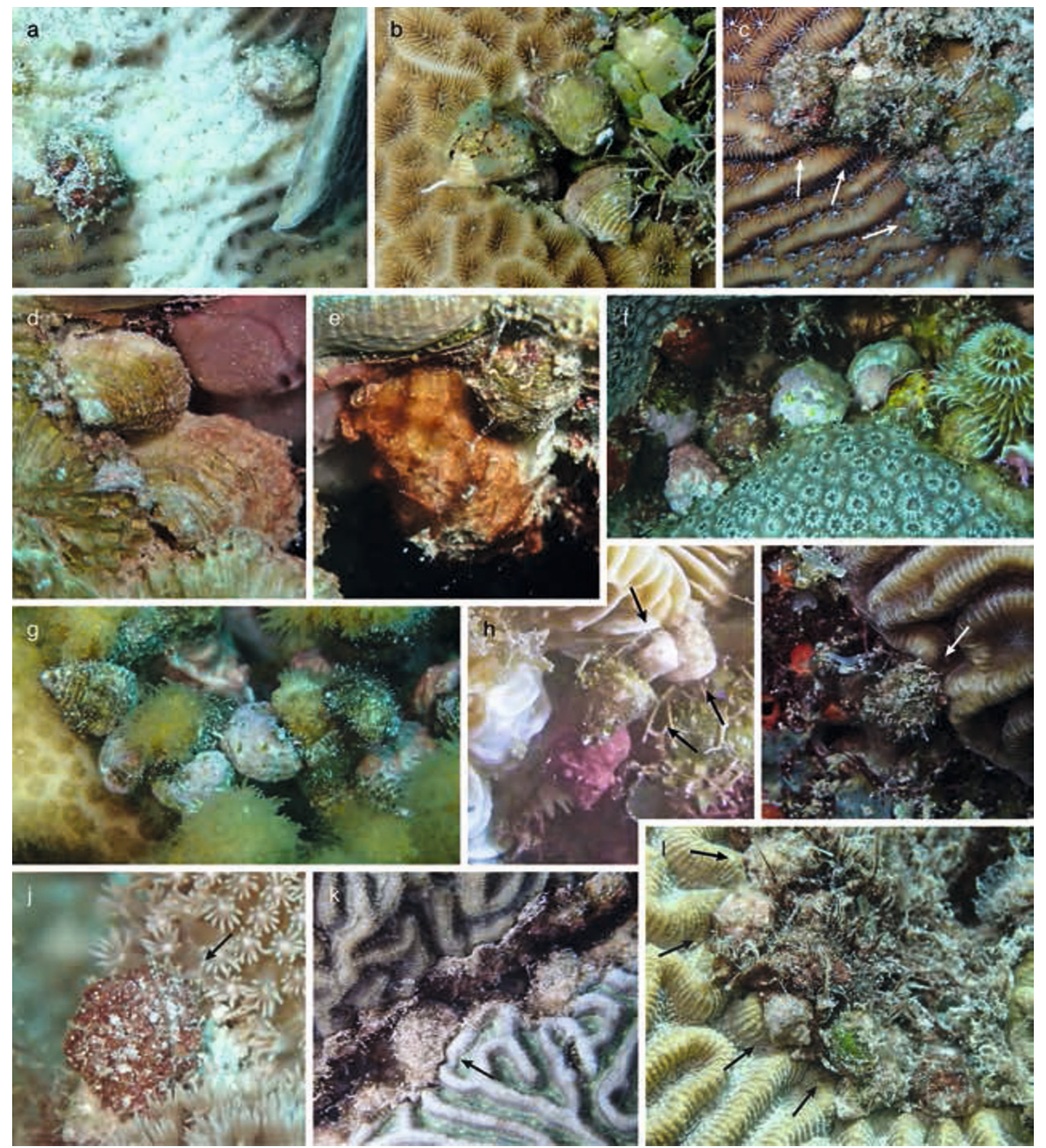

Fig. 3. In-situ photos of Coralliophila galea, associated with various host species: Agaricia agaricites (a); A. humilis (b); A. lamarcki (c); Colpophyllia natans (d-e); Orbicella annularis (f); Madracis auretenra (g); Meandrina meandrites (h); Diploria labyrinthiformis (i); Porites porites (j); Pseudodiploria clivosa (k); P. strigosa (1). One of the snails has its proboscis extended into the mouth of a polyp (b). Arrows: hidden snails.

specimens): 442 shells of $C$. galea, 55 of $C$. caribaea and seven of $C$. curacaoensis sp. nov. (Table 3). Principal component analysis on landmark data of all three species revealed six axes, explaining $71.0 \%$ of all observed variance, with an ICC $>0.80$ that could therefore be considered repeatable. While overlap in shell 

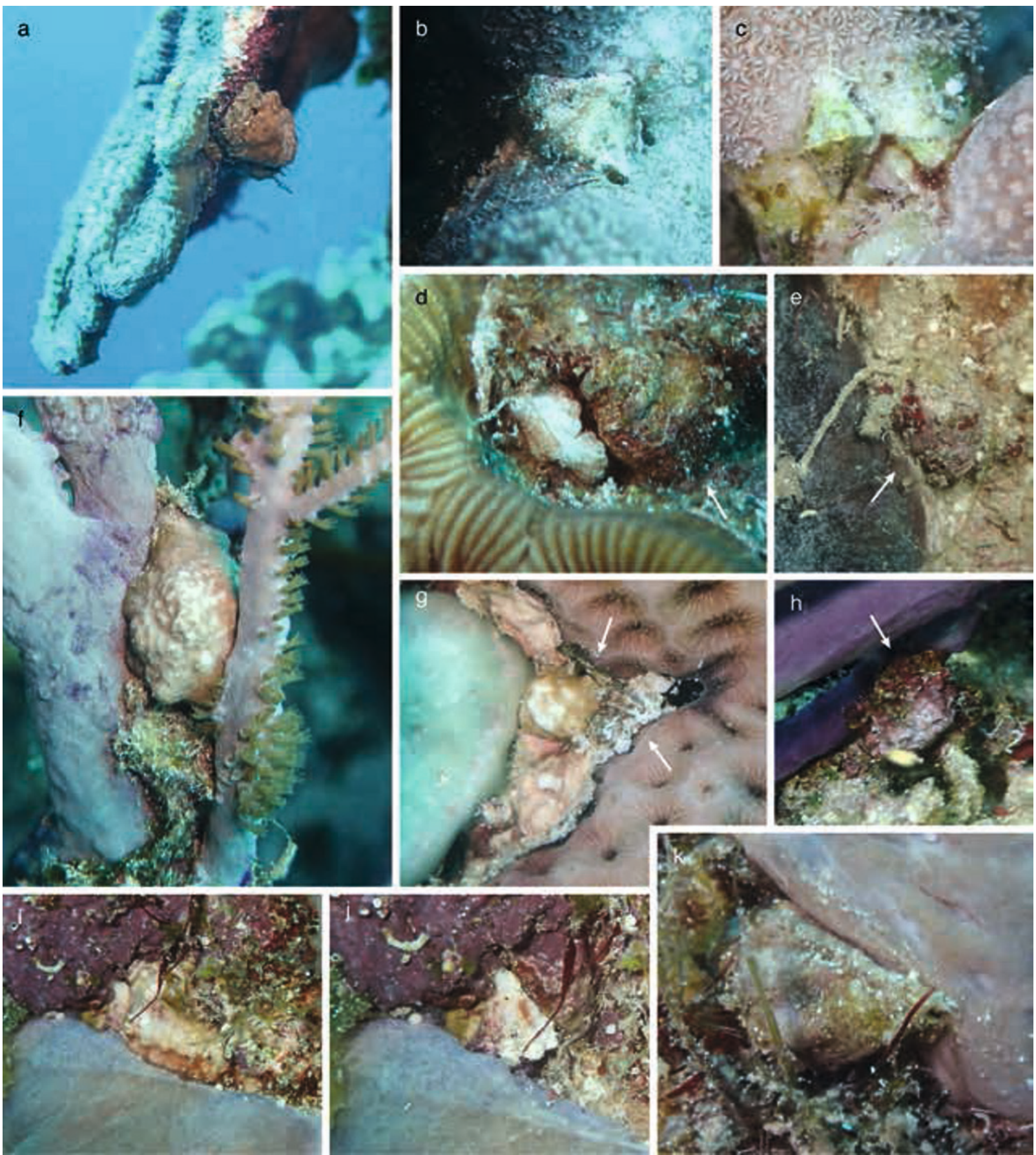

Fig. 4. In-situ photos of Coralliophila caribaea, associated with various host species: Mycetophyllia ferox (a); Porites porites (b-c); Colpophyllia natans (d); Montastraea cavernosa (e); Antillogorgia sp. (f); Siderastrea siderea (g); Gorgonia sp. (h); Pseudoplexaura sp. (i-k). Some snails have their proboscis extended into the mouth of a polyp (c-e). Two individuals of $C$. caribaea co-occurred with a single individual of $C$. galea (d: arrow). The tight clustering of some snails on a single coral colony is shown by removal of the snail on top (i-j). Arrows: hidden snails.

shape between species existed, all three species were separated on the first and third PC axis, which explained $31.2 \%$ and $10.4 \%$ of all variances in shell shape
(Fig. 8). On the first PC axis, Coralliophila galea shells separated from both $C$. caribaea $(p<0.0001)$ and $C$. curacaoensis sp. nov. $(p<0.0001)$. On the third PC 

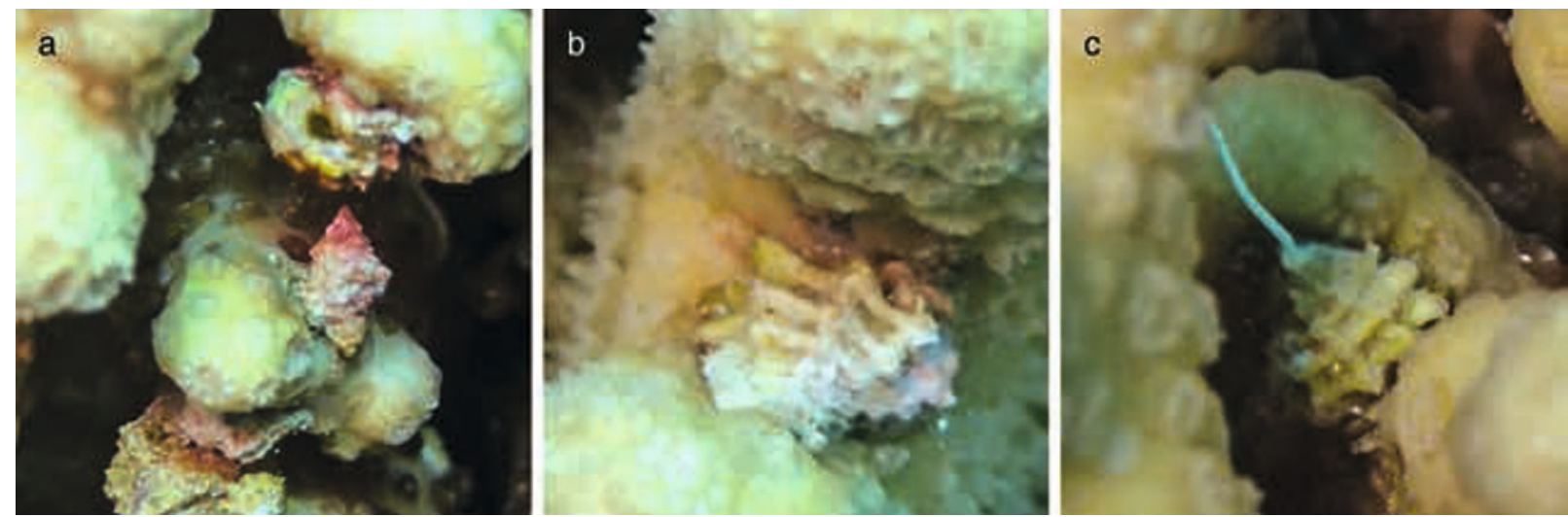

Fig. 5. In-situ photos of Coralliophila curacaoensis sp. nov. in association with Madracis auretenra. One snail has its proboscis extended into the mouth of a polyp (c).
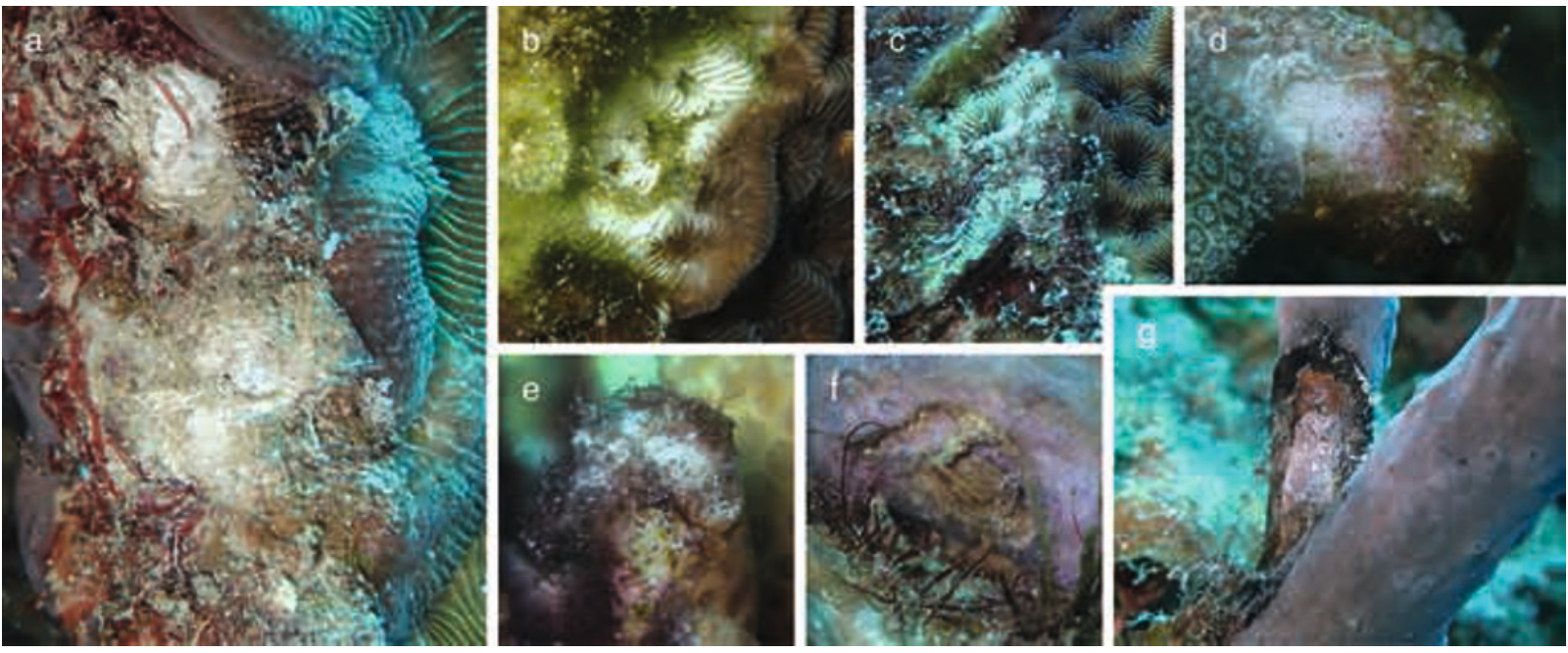

Fig. 6. Removed coral tissue of various host coral species underneath Coralliophila individuals: Colpophyllia natans (a); Agaricia agaricites (b-c); Porites furcata (d); Madracis auretenra (e); Pseudoplexaura sp. (f); Eunicea sp. (g).
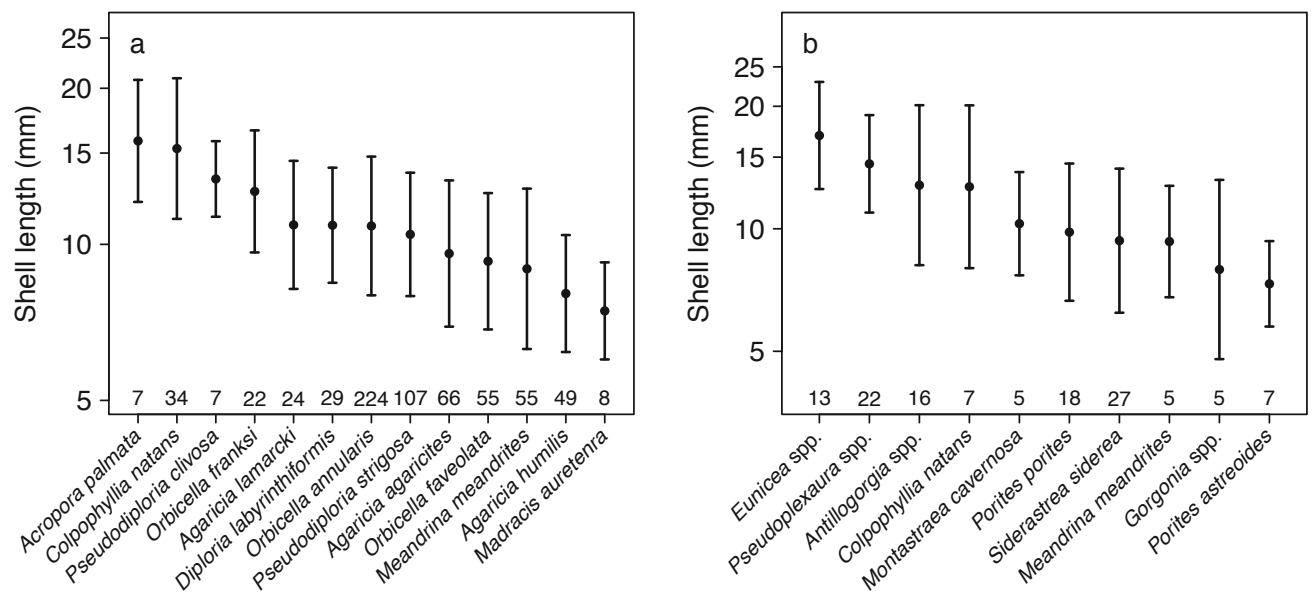

Fig. 7. Host-dependent size structuring of Coralliophila galea (a) and C. caribaea (b). Error bars represent one standard deviation. Shell length is plotted on a logarithmic scale; numbers above axis represent sample sizes. For significant differences, see Tables S2 and S3 for C. galea and C. caribaea, respectively (Online Supplementary Material 4). 
a

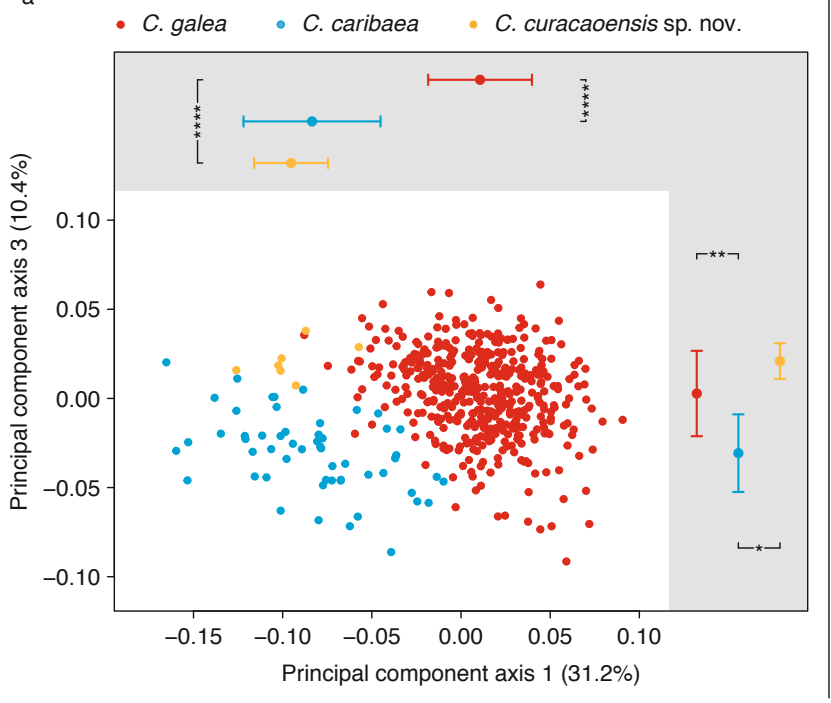

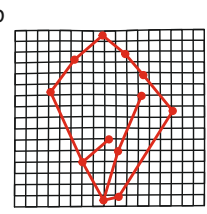

c

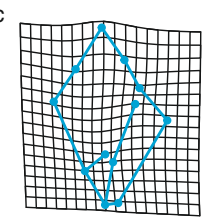

d

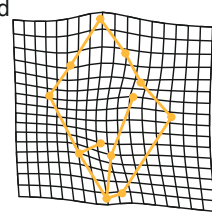

Fig. 8. Interspecific variation in shell shape of three Coralliophila spp. by principal component analysis (a). The first and third axes of the PCA are plotted. Mean principal component scores of Coralliophila spp. are shown in the margins. Error bars represent one standard deviation. Significant differences: $*: p<$ $0.05 ; * *: p<0.01 ; * * * *: p<0.0001$. Mean shell shapes of the three species are shown (b-d), grids are warped against the mean shell shape of Coralliophila spp.

\begin{tabular}{lrrrrrr}
\hline & \multicolumn{3}{l}{ Coralliophila galea } & \multicolumn{3}{c}{ Coralliophila caribaea } \\
\hline & $\mathbf{R}^{2}$ & $\mathbf{F}$ & $\boldsymbol{p}$ & \multicolumn{1}{c}{$\mathbf{R}^{2}$} & $\mathbf{F}$ & $\boldsymbol{p}$ \\
\hline Shell length & 0.072 & 37.72 & 0.001 & 0.041 & 3.13 & 0.038 \\
Host order & - & - & - & 0.093 & 7.17 & 0.001 \\
Host species & 0.069 & 3.30 & 0.001 & 0.183 & 1.76 & 0.013 \\
Depth & 0.006 & 2.90 & 0.002 & 0.031 & 2.35 & 0.023 \\
Host species $\times$ Shell length & 0.046 & 2.20 & 0.001 & 0.133 & 1.46 & 0.004 \\
Host species $\times$ Depth & 0.030 & 1.75 & 0.001 & 0.092 & 2.36 & 0.001 \\
Residuals & 0.777 & - & - & 0.429 & - & - \\
\hline
\end{tabular}

Table 4. Factors used in the models of shell shape of both Coralliophila galea and $C$. caribaea. Shell length was transformed with the natural logarithm; $p$ values are based on 1,000 permutations. axis, shells from $C$. curacaoensis sp. nov. were also separated from $C$. caribaea shells $(p=0.016)$. In total, species identity accounted for $19.5 \%$ of all observed variance in shell shape.

Intraspecific variation in shell shape of both $C$. galea and $C$. caribaea was high (Figs. 9-10). For $C$. galea, principal component analysis again revealed five repeatable axes (ICC $>0.80$, explaining $62.3 \%$ of variance in shell shape). For $C$. caribaea, four repeatable axes were found (ICC $>0.80$, explaining $72.2 \%$ of variation) by the principal component analysis. Compared to C. galea, the first two PC axes of C. caribaea explained more of the intraspecific variance in shell shape. Most of the intraspecific variation on the repeatable PC axes of both species was related the shape and relative size of the shell spire. Despite high intraspecific variation, no distinct ecotypes could be distinguished in either species, as all specimens clustered together into one cloud without gaps.
For both C. galea and C. caribaea, all factors and interactions had a significant influence on shell shape (Procrustes ANOVA model; Table 4). Though all tested factors contributed to shell shape, the explained variance in shell shape by any factor was low $\left(\mathrm{R}^{2}<\right.$ 0.20 for all factors and interactions) and residual variance was high $\left(\mathrm{R}^{2}=0.777\right.$ for $C$. galea and $\mathrm{R}^{2}=0.429$ for C. caribaea).

Host-associated differences in shell shape accounted for some of the intraspecific variation in shell shape of Coralliophila spp. In C. galea, differences in host species explained $6.9 \%$ of variance in shell shape (Table 4). Among snails from different hosts species, eleven pairwise differences in shell shape were found (Table S4 in Online Supplementary Material 4), that, even though statistically significant, were subtle, and strong overlap in shell shape existed among snails from different host species (Figs. 9-10).

Shell shape of $C$. caribaea also differed among host 

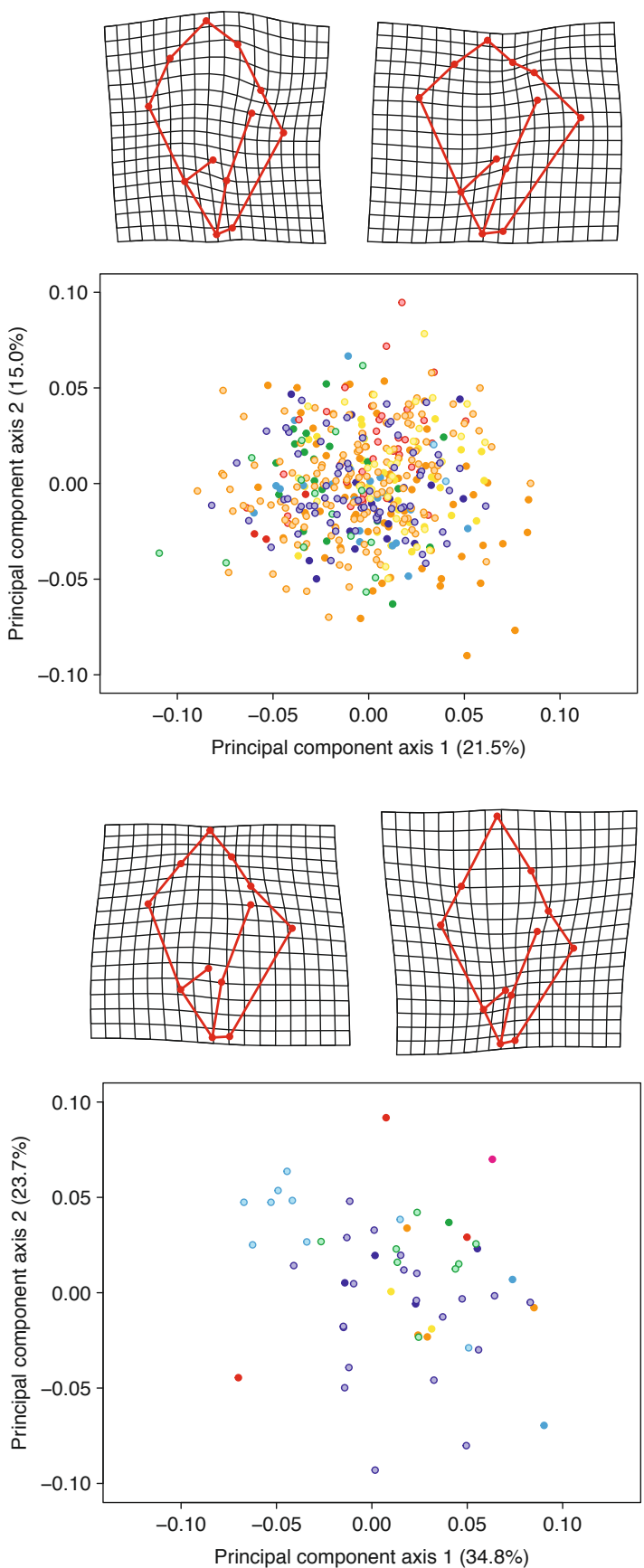

- Acropora palmata

- Agaricia agaricites

- Agaricia humilis

- Agaricia lamarcki

- Colpophyllia natans

- Diploria labyrinthiformis

- Meandrina meandrites

Orbicella annularis

Orbicella faveolata

- Orbicella franksi

- Pseudodiploria clivosa

- Pseudodiploria strigosa
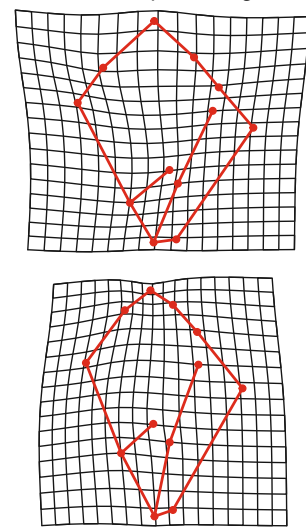

- Antillogorgia sp.

- Eunicea sp.

- Pseudoplexaura sp.

- Colpophyllia natans

- Meandrina meandrites

- Montastraea cavernosa

- Porites astreoides

- Porites furcata

- Porites porites

- Siderastrea siderea
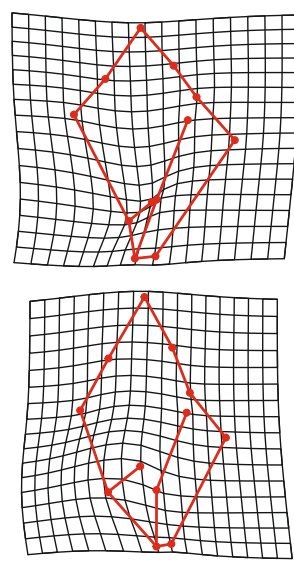

Fig. 9. Intraspecific variation of shell shape in Coralliophila galea. The first two axes of the principal component analysis are plotted, with colours coding for host species. Warped grids represent the extreme values of the first and third $\mathrm{PC}$-axis. Grids are warped against the mean shell shape of $C$. galea.
Fig. 10. Intraspecific variation of shell shape in Coralliophila caribaea. The first two axes of the principal component analysis are plotted, with colours coding for host species. Warped grids represent the extreme values of the first and third PC-axis. Grids are warped against the mean shell shape of C. caribaea. species. Firstly, snails originating from hosts of the order Alcyonacea and snails from Scleractinia differed in shell shape, which accounted for $9.3 \%$ of the observed variance in shell shape (Table 4). At the host genus level, two pairwise differences were significant (Table S5).
Depth had a small, though significant, effect on shell shape in both $C$. galea and C. caribaea (Table 4). On top of an overall effect of depth, and a small host-specific effect of depth was observed in both $C$. galea and C. caribaea. 

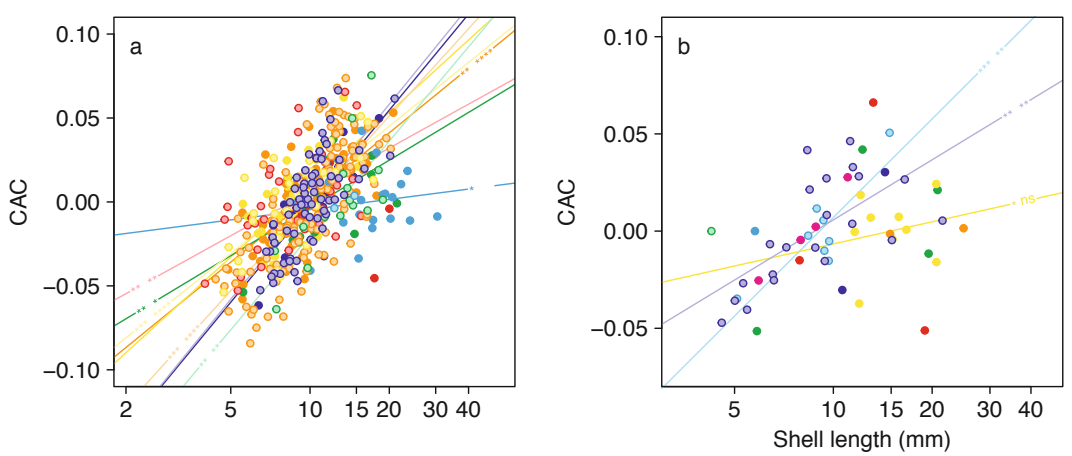

Fig. 11. Allometric patterns in Coralliophila galea (a) and C. caribaea (b). Common allometric component (CAC) is plotted against shell length (a). Separate regressions for host species with five or more specimens are plotted, symbols on the lines represent the $\mathrm{R}^{2}$-value (first symbol) and $p$-value (second symbol) of the regression: ns: $p>0.05 ; *: \mathrm{R}^{2}<0.1, p$ $<0.05 ; * *: \mathrm{R}^{2} \geq 0.1, p<0.01 ; * * *: \mathrm{R}^{2} \geq$ $0.5, p<0.001 ; * * * *: \mathrm{R}^{2} \geq 0.75, p<0.0001$. Points and regression lines per host are colour-coded as in Figs. 9-10. Shell length is plotted on a logarithmic scale.
Since $C$. curacaoensis sp. nov. only occurred on $M$. auretenra, host-related differences could not be assessed. Shell length did not contribute to intraspecific variations in shell shape within this species $(\mathrm{F}=2.1 ; p$ $=0.070$ ).

\section{Allometry}

Allometric patterns were important in determining the shell shape in both $C$. galea and C. caribaea. In both species, shell length explained minor variation in shell shape $\left(\mathrm{R}^{2}=0.072 ; p=0.001\right.$ and $\mathrm{R}^{2}=0.041 ; p=0.049$ for $C$. galea and C. caribaea, respectively), and these relationships depended on the host on which snails were found (shell length and host species interaction, $\mathrm{R}^{2}=0.046 ; p=0.001$ and $\mathrm{R}^{2}=0.133 ; p=0.004$ for $C$. galea and $C$. caribaea, respectively). The presence of such host-associated differences was also implied by the regressions between the CAC and shell length, where the slope of these linear regressions varied among snails associated with different host species (regressions were only done for hosts with $\geq 5$ specimens; Fig. 11). Post-hoc tests further confirmed the presence of host-associated differences in allometric patterns in both $C$. galea and C. caribaea. Predicting the hypothetical shell shape of shells associated with a certain host species for a specific shell length, based on linear regressions of PC scores against shell length, clearly showed these differences (Fig. 12). Allometric patterns were subtler in $C$. caribaea compared to $C$. galea. In case of $C$. galea, both the distance (i.e., amount of change per unit of growth) and correlation (i.e., the direction of change) among vectors of shell length were, after Bonferroni corrections $(n=45)$, different for six pairs of host species (Fig. 12a; Table S6 in Online Supplementary Material 4). In C. caribaea, the correlation of vectors differed for a single pair of host species, while no differences were observed in the distances among vectors (Fig. 12b; Table S7 in Online Supplementary Material 4).

\section{Replication error in morphometric data}

Shell lengths of a random selection of snails $(n=65)$ were measured in triplicate. Average distance from the mean of these three measurements was $0.03 \mathrm{~mm}$ for shell length. Error in landmark data was assessed based on 53 out of the 65 specimens ( 47 specimens of C. galea, six specimens of C. caribaea). Replication errors were slightly higher for $C$. galea than for $C$. caribaea. Error in digitizing landmarks was $3.6 \%$ in C. galea compared to $1.7 \%$ in C. caribaea. The total error, which included inconsistencies in parallax as well, was $11.4 \%$ in C. galea and $4.0 \%$ in C. caribaea. Replication error in C. curacaoensis sp. nov. was not calculated.

\section{Sex ratios}

Sex could be determined for 609 specimens of $C$. galea and 115 specimens of C. caribaea. In C. galea, $74.4 \%$ were male. With $64.3 \%$, the fraction of males in C. caribaea was lower $(p=0.030)$. Females were larger than males in both $C$. galea $\left(\chi^{2}=133.9 ; p<0.0001\right)$ and $C$. caribaea $(\mathrm{F}=35.1 ; p<0.0001)$. Both males and females were found on all but one host species $(C$. caribaea on Porites furcata Lamarck, 1816, on which only female specimens were found). Sex ratios within $C$. galea differed among snails associated with different host species ( $p=0.0004$; only including hosts with $\geq 5$ specimens; Fig. 13a). After Bonferroni correction of $p$-values $(n=78)$ one pair remained significant: snails associated with Agaricia humilis Verrill, 1901 had a higher male to female ratio than snails associ- 
a
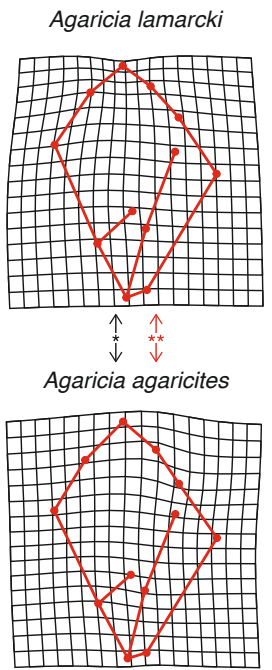
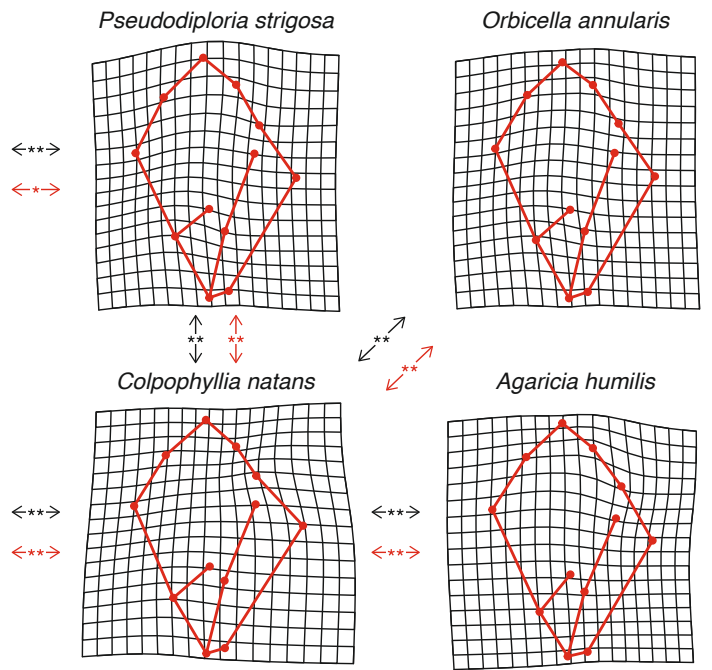

b

Siderastrea siderea
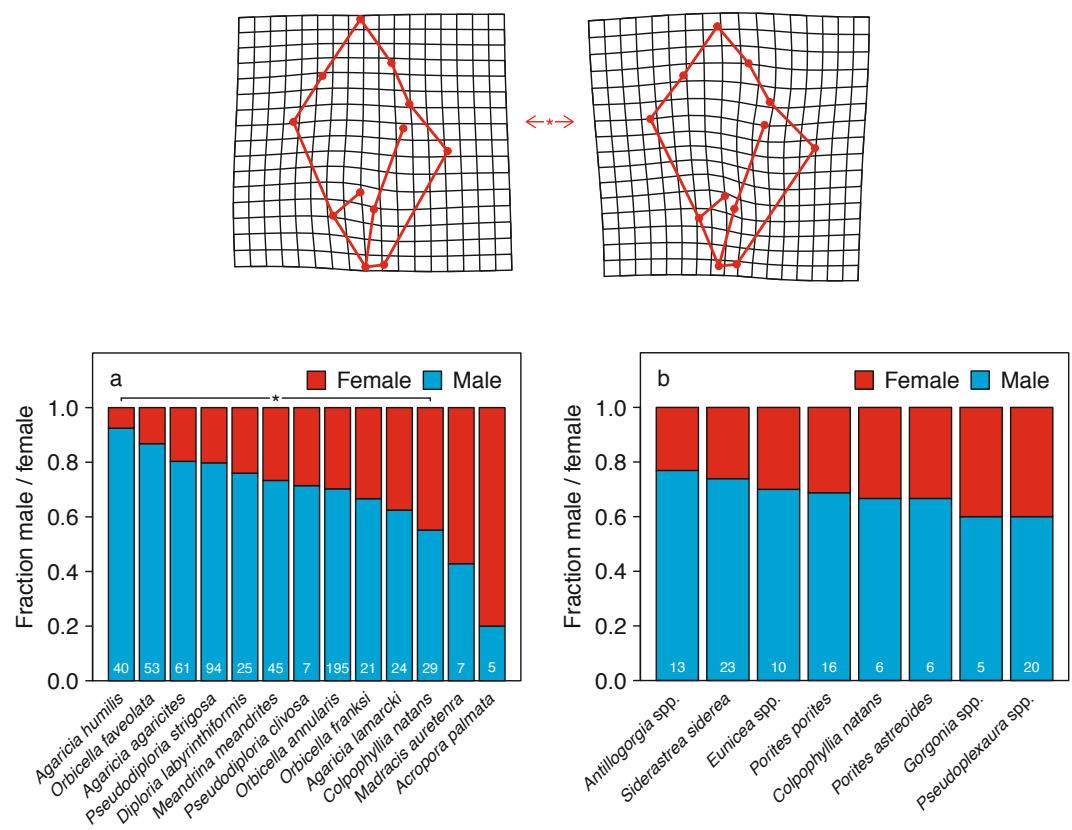

Fig. 12. Predicted shell shape of Coralliophila galea (a) and C. caribaea (b) shells of different shell lengths associated with different host species, based on principal component scores of repeatable axes. Grids show the predicted shape of the largest specimen collected from the respective host, warped against the predicted shape of the smallest specimen collected. Black arrows indicate significant differences in the amount of change in shell shape per unit of growth, red arrows indicate significant differences in the direction of change in shell shape. Significant differences: *: $p<0.05 ; * *: p$ $<0.01$.

Fig. 13. Sex ratios of Coralliophila galea (a) and C. caribaea (b) associated with different host species. Host species are ranked based on the fraction of males. After Bonferroni correction for multiple pairwise comparisons, no significant differences remained in $C$. caribaea. Significant differences: $*: p<0.05$. ated with Colpophyllia natans (Houttuyn, 1772) ( $p=$ 0.032). Within C. caribaea, no variation in sex ratios between host species existed ( $p=0.975$; only including hosts with $\geq 5$ specimens; Fig. 13b). Sex ratio of $C$. caribaea associated with alcyonaceans $(66.0 \%$ male) and scleractinians (63.1\% male) was similar as well ( $p$ $=0.845$ ).

Within $C$. galea, mean length of females per host species correlated with the mean length of males $\left(\mathrm{R}^{2}=\right.$ 0.707; $p=0.0002$ ) (Fig. 14a). The same was observed in C. caribaea $\left(\mathrm{R}^{2}=0.614 ; p=0.011\right)$ (Fig. 14b).

\section{Genetics}

The three Caribbean Coralliophila species clustered into three well-supported, separate clades on the phylogenetic tree (posterior probability $(\mathrm{PP})=0.997-1.000$; Fig. 15). Phylogenetic trees constructed for both markers separately showed the same pattern (Online Supplementary Material 5). No monophyletic Caribbean cluster was found: Coralliophila curacaoensis sp. nov. is the sister species of a group consisting of both C. fontanangioyae Smriglio and Mariottini, 2000 and C. meyen- 

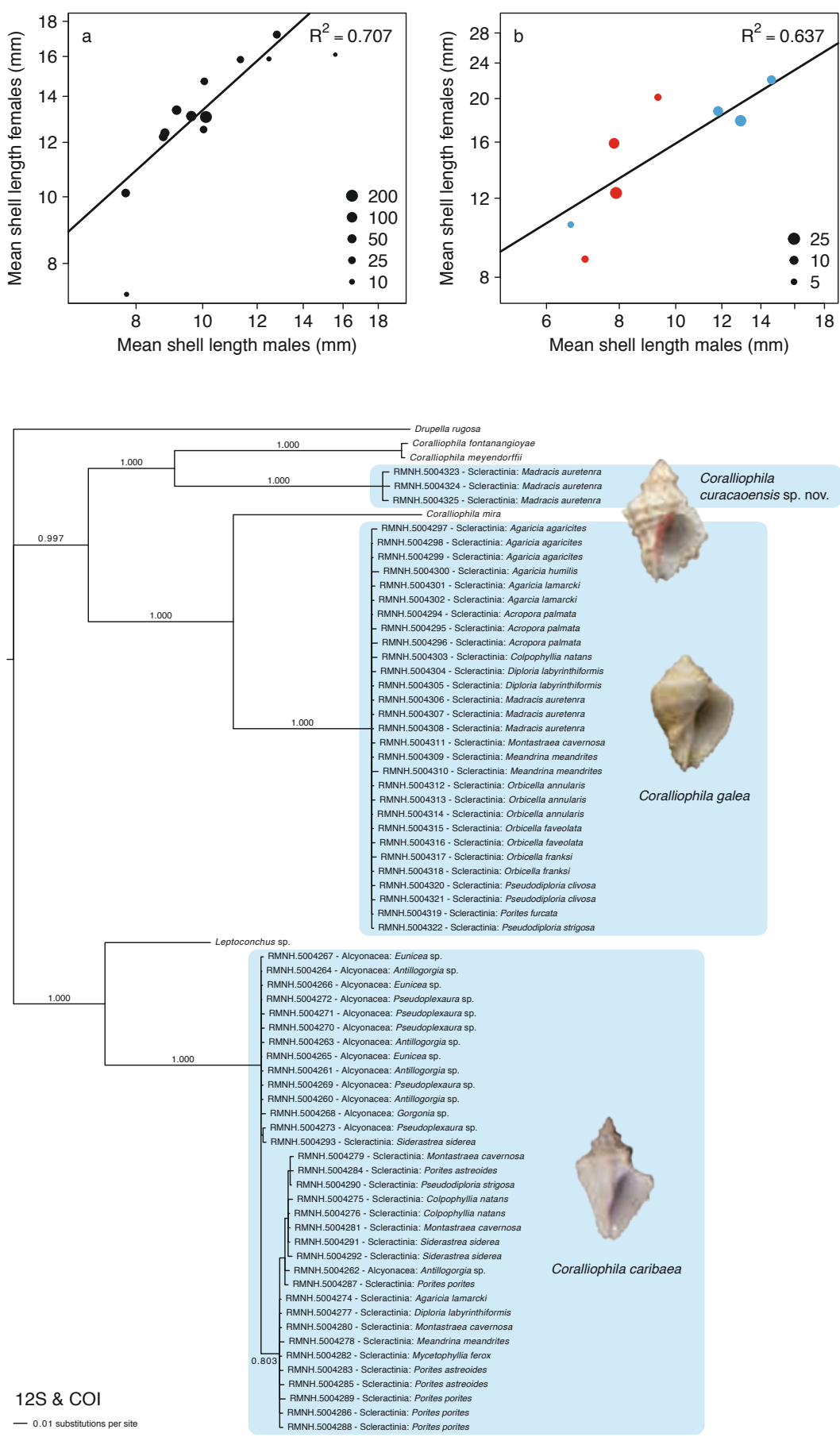

Fig. 14. Mean shell length against the proportion of male snails per host species of Coralliophila galea (a) and C. caribaea (b). Regression was not significant for $C$. caribaea (b). In the linear regression, individual points were weighed per number of observations per host species. Number of observations is represented by the size of points. Points are coloured by host order (b), blue for Alcyonacea, red for Scleractinia.
Fig. 15. Phylogenetic tree based on the $12 \mathrm{~S}$ rRNA (12S) and cytochrome $c$ oxidase subunit I (COI) markers of a selection of the collected Coralliophila spp. specimens. The three shaded clades represent the three species of Coralliophila found in the present study. Within the shaded clusters, tip labels represent the host order and host species with which the snail was associated. Specimens outside the shaded cluster are previously published sequences. Branch labels are posterior probabilities (PP). Intraspecific $\mathrm{PP}$-values are not shown (except for the main clade within $C$. caribaea) and were all lower than 0.90. Scale bar: 0.01 substitutions per site. dorffii (Calcara, 1845) from the Eastern Atlantic and the Mediterranean; C. galea is sister of C. mira (Cotton and Godfrey, 1932) from the Indo-Pacific, and C. caribaea is sister of the Indo-Pacific Leptoconchus sp. Hence, the genus Coralliophila is also not monophyletic.
No host-associated genetic divergence was found within Coralliophila galea ( $p=0.458$ and $p=0.342$ for $12 \mathrm{~S}$ and COI, respectively). In C. caribaea on the other hand, a small divergence (mean uncorrected distance of $0.6 \%$ for $12 \mathrm{~S}$ and $2.9 \%$ for $\mathrm{COI}$ ) was 


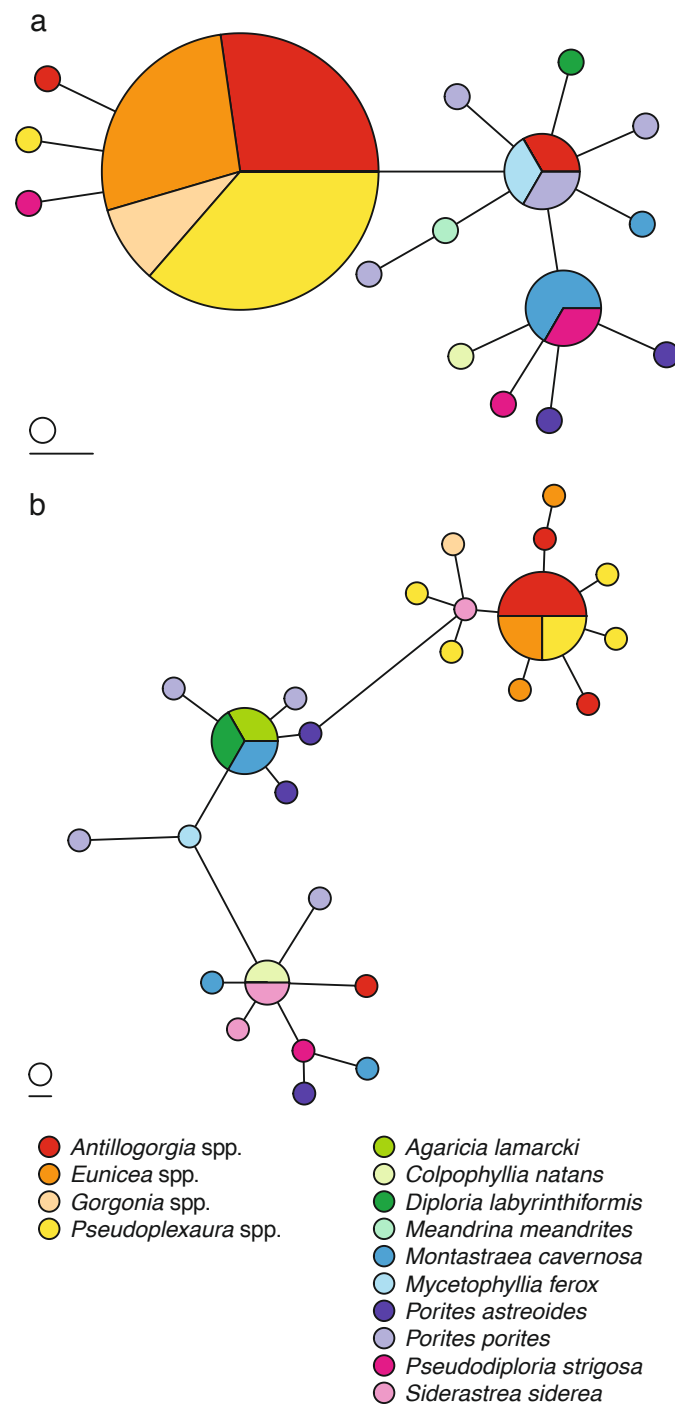

Fig. 16. Haplotype networks based on an infinite site model (using simple, uncorrected distances) of the sequenced specimens C. caribaea, both for the markers $12 \mathrm{~S}$ rRNA (12S) (a) and cytochrome $c$ oxidase subunit I (COI) (b). Haplotype are coloured based on host species with which the haplotypes were associated, size represents the frequency of haplotypes. Length between haplotypes is based on the number of mutations between haplotypes. Circles and lines in the bottom left of each figure represent a frequency of one and one mutation between haplotypes respectively.

found between snails associated with Alcyonacea and those associated with Scleractinia $(p<0.0001$ for both $12 \mathrm{~S}$ and $\mathrm{COI}$ ). This genetic structuring within C. caribaea was also visible on the phylogenetic tree, as $C$. caribaea collected from Scleractinia cluster all on a single branch (with one exception), although the

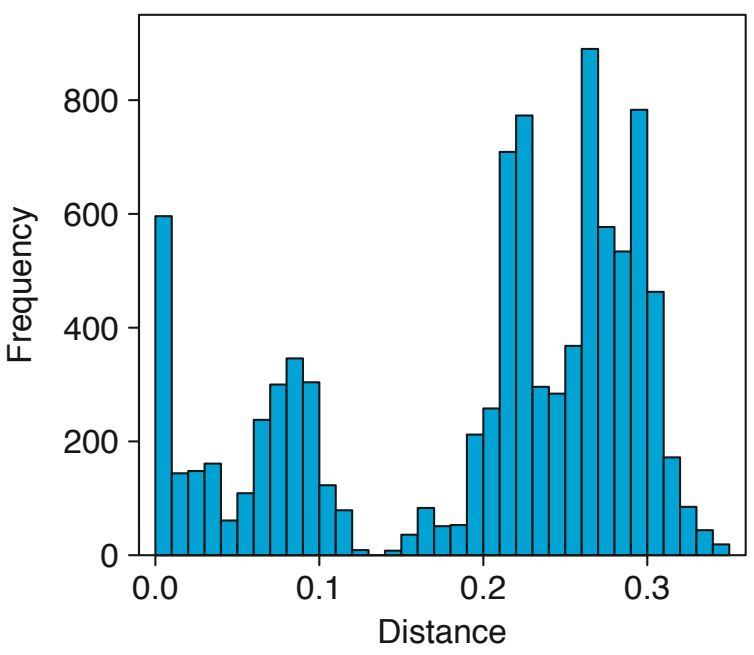

Fig. 17. Automatic Barcode Gap Discovery analysis based on Kimura two-parameter distances of a dataset of coralliophiline cytochrome $c$ oxidase subunit I (COI) sequences, including the Coralliophila spp. specimens sequenced in the present study.

support value for this branch was low ( $\mathrm{PP}=0.803)$. There was no host-associated divergence within $C$. caribaea from scleractinian corals $(p=0.213$ and $p=$ 0.971 for $12 \mathrm{~S}$ and COI, respectively) or alcyonacean hosts $(p=0.941$ and $p=0.945$ for $12 \mathrm{~S}$ and COI, respectively).

The small divergence among $C$. caribaea individuals associated with either scleractinians or alcyonaceans was also observed in the haplotype networks constructed for both markers (Fig. 16). With one exception for COI, haplotypes were unique to snails associated with hosts from either Scleractinia or Alcyonacea. In addition, haplotypes of snails associated with alcyonaceans mostly (with one exception for both markers) clustered together on a single branch in the haplotype network. Snails associated with scleractinians formed (again, with one exception for both markers) the other branches in the networks. The two clusters were separated by two mutations for $12 \mathrm{~S}$ and eight mutations for COI. No clear correlation between host species and haplotype was present within $C$. galea.

The ABGD analysis based on COI, using a more extensive dataset of coralliophiline snails, proposed nine different groupings of specimens into MOTUs, depending on the a priori boundary between intra- and interspecific divergence. A histogram of the frequencies of pairwise Kimura two-parameter (K2P) distances revealed a multimodal distribution, with the lowest 
minimum frequency around a $\mathrm{K} 2 \mathrm{P}$ distance of 0.05 (Fig. 17). Using this value as a boundary between intraand interspecific divergence, the coralliophiline dataset can be subdivided into 16 MOTUs. At this value, the specimens of C. galea, C. caribaea and C.curacaoensis sp. nov. are clustered into three different MOTUs, in agreement with the phylogenetic tree. The divergence within $C$. caribaea was confirmed to be intraspecific, not revealing any cryptic species, using this boundary value of 0.05 .

\section{Discussion}

Most of the host species associations for Coralliophila galea and C. caribaea found in the present study have been previously recorded (Miller, 1981; Brawley and Adey, 1982; Hayes, 1990a; Bruckner et al., 1997; Del Monaco et al., 2010; Potkamp et al., 2017). Feeding of C. galea on Orbicella annularis was found to be infrequent around 1970 (Robertson, 1970; Ott and Lewis, 1972), but later clearly impacted reef communities (Brawley and Adey, 1982; Knowlton et al., 1988, 1990; Hayes, 1990a; Bruckner et al., 1997; Baums et al., 2003b). Predation pressure by Coralliophila spp. may depend on prey preference. Multiple studies concluded that $C$. galea can cause much damage to Acropora spp., and to a lesser extent to Orbicella spp. (Brawley and Adey, 1982; Knowlton et al., 1988, 1990; Baums et al., 2003b). On some host species, such as $O$. annularis, large aggregations of $C$. galea snails can be found. Aggregations of C. caribaea were generally smaller. Large aggregations of snails of the genus Drupella Thiele, 1925 (Muricidae: Ergalataxinae) can have a damaging effect on Indo-Pacific reef corals (Hoeksema et al., 2013; Moerland et al., 2016; Scott et al., 2017; references herein), suggesting that large $C$. galea aggregations are harmful as well, confirming earlier findings (Bruckner et al., 1997; Knowlton et al., 1988, 1990; Hayes, 1990a; Baums et al. (2003a, 2003b). Predation on Alcyonacea by C. caribaea is also relevant, as gorgonians represent a large part of Caribbean and Brazilian reef communities (e.g. Preston and Preston, 1975; Sánchez et al., 1998, 2003; Dias and Gondim, 2016; Lau, 2016). However, few studies have been conducted on the ecology and prey preference of C. caribaea.

The physiology of coralliophilines, with a proboscis used in feeding, helps to optimally exploit energy from their hosts (Ward, 1965; Robertson, 1970). The IndoPacific C. violacea (Kiener, 1836), which usually, like its Caribbean congeners, also feeds along the coral margin, has adopted a prudent feeding strategy by exploiting energy sinks along the margin of its hosts, thereby causing minimal damage (Oren et al., 1998). Similar behaviour in Caribbean Coralliophila spp., combined with an absence of large feeding scars on most host species, suggests that $C$. galea and C. caribaea employ similar strategies (Martin et al., 2014). If so, the high feeding rates of $C$. galea on Orbicella spp. calculated by Baums et al. (2003b), which were based on the energetic requirements of $C$. galea rather than on feeding scars, might be an overestimation of the actual feeding rates. Coralliophila curacaoensis sp. nov. also used its proboscis for feeding on its only known host, Madracis auretenra. As this coral is common across the Caribbean, it is likely that this new snail species will also be discovered at other localities.

\section{Morphology}

A large range in shell sizes was observed within Coralliophila spp. Females were on average larger than males, which is consistent with the fact that $C$. galea is a protandrous hermaphrodite (Baums et al., 2003a; Johnston and Miller, 2006). The same pattern was observed within $C$. caribaea, suggesting a similar life history, which has been suggested to be a synapomorphous trait among the Coralliophilinae (Richter and Luque, 2002, 2004). In addition, host-associated size structuring existed within both C. galea and C. caribaea populations. Differences in shell length related to host species have been observed before within $C$. galea (Hayes, 1990a; Bruckner et al., 1997; Baums et al., 2003a; Johnston and Miller, 2006). Ecotypes with distinctive shell lengths have also been observed in their Mediterranean congener $C$. meyendorffii, where small snails are associated with scleractinian hosts and large snails are associated with sea anemones (Oliverio and Mariottini, 2001b;Kružić et al., 2013). The results of the present study confirm and expand this pattern of host-associated size structuring in C. galea, and show that it also exists in C. caribaea.

Migration between host species with age could induce host-associated size structuring. In the Indo-Pacific corallivorous snail Drupella cornus (Röding, 1798), prey preference seems to change as snails age (Black and Johnson, 1994; McClanahan, 1997; Schoepf et al., 2010; Moerland et al., 2016). Age-dependent host preference would result in a clear host-associated size structuring as seen within Coralliophila spp. However, no evidence exists to support that C. galea or 
C. caribaea migrate between host species. As both male and female snails were found on all but one host species (for which more than one specimen was collected) of $C$. galea, it seems unlikely that size-related migration between specific host species also occurs in C. galea, i.e., that juvenile snails (which would all be males) are associated with different host species than adults.

Another potential mechanism behind host-associated size structuring can result from size-dependent susceptibility to predation (Johnston and Miller, 2006). Selective predation on larger snails, which on some host colonies are more exposed than smaller snails, would result in host-associated size structuring. Wells and Lalli (1977) hypothesized further that brooding females of C. galea are, compared to C. caribaea, more vulnerable to predation because of the placement of egg capsules in the mantle cavity. Predation on larger snails would therefore decrease mean shell size and skew the male to female ratio. Variation in male to female ratios, as observed in C. galea, would be expected in case of size-specific predation. However, information on predation on Coralliophila spp. is limited, resulting from laboratory experiments or anecdotal observations (Goldberg 1971; Wells and Lalli, 1977; Baums et al., 2003a; Sharp and Delgado, 2015).

Besides a large range in shell size, high intraspecific variation in shell shape was found in both C. galea and C. caribaea. Despite this high intraspecific variation, no distinct ecotypes based on shell shape could be identified within either species, though weak host-associated differences in mean shell shape and allometric patterns existed in both C. galea and C. caribaea. Differences in shell shape were subtle with strong overlap among snails associated with different host species. Tested factors explained little of the observed variation in the models of shell shape suggesting the presence of factors not considered here.

Differences in growth rate could also explain hostdependent size structuring as well as the intraspecific variation in shell shape and allometry (Kemp and Bertness, 1984; Boulding and Hay, 1993; Chiu et al., 2002; Urdy et al., 2010a, 2010b). While growth rate has not been measured in the present study, the strong correlation between average male and female size separated by host species (assuming sex-change occurs at the same relative age) is consistent with the idea that growth rates differ among snails associated with different host species, confirming previous studies (Baums et al., 2003b; Johnston and Miller, 2006). Such differences in growth rate may result from, for example, differences in nutritional quality of host tissue (Szmant et al., 1990), anti-predatory mechanisms of host species (Barnes, 1970; Brauer et al., 1970; Moore and Huxley, 1976; Glynn and Krupp, 1986; Pawlik et al., 1987; Harvell et al., 1988; Harvell and Fenical, 1989; Van Alstyne and Paul, 1992; Pawlik, 1993; O'Neal and Pawlik, 2002; Gochfeld, 2004; Lages et al., 2010), predation pressure on snails (Fraser and Gilliam, 1992; Connell, 1998; Nakaoka, 2000) or intraspecific competition (Williamson et al., 1976; Cameron and Carter, 1979), among other factors. Baums et al. (2003b) suggested that differences in environment or nutrition (and by extension, host species) played a role in the growth rate of C. galea, Johnston and Miller (2006) suggested a role for nutritional quality and secondary metabolites, as well as intraspecific competition in the population structure of C. galea. Shell morphology has also been related to vulnerability to predation (Ebling et al., 1964; Kitching et al., 1966; Vermeij, 1974, 1993; Cotton et al., 2004). Variation of these factors across the range of hosts species, with vastly different colony shapes, may therefore result in host-dependent variation in shell size, shape and allometry as observed in the present study. However, little is known about the extent to which these factors play a role in corallivores in general or in Coralliophila spp. specifically. The mechanisms behind the observed patterns in shell size and shape remain therefore largely unknown.

\section{Genetics}

No host-associated genetic divergence was observed within $C$. galea: specimens failed to cluster by host species in the Bayesian analysis and genetic distances in snails were not significantly larger between host species than the distances within host species. Haplotypes were not correlated with host species. Johnston et al. (2012) also did not observe host-specific clustering in genetic data and only found a small genetic divergence between $C$. galea snails associated with Acropora palmata, Orbicella spp. and Mycetophyllia spp. Two ecotypes of the Mediterranean congener C. meyendorffii, which are associated with different host species, are also not genetically divergent (Oliverio and Mariottini, 2001b).

In contrast to $C$. galea, a host-associated genetic divergence was found within C. caribaea. Snails associated with alcyonaceans were genetically distinct from snails associated with scleractinians with one exception either way. The genetic divergence within $C$. caribaea was however relatively small. On the phylogenetic tree, the support value for the branch with nearly all snails 
associated with scleractinians was low. Haplotypes differed on a few loci between snails associated with scleractinians and alcyonaceans (two mutations between the haplotype cluster mostly associated with alcyonaceans and the other haplotypes for $12 \mathrm{~S}$, eight mutations for COI), and correlation of haplotypes with host order was not perfect. The K2P distance between specimens associated with alcyonaceans and scleractinians fell below the threshold between interspecific and intraspecific divergence as determined in the ABGD analysis. These observations all indicate that the divergence within $C$. caribaea is of relatively recent origin. Genetically diverged host races have mostly been described in insects (e.g. Feder et al., 1988; McPheron et al.; 1988; Powell et al., 2014), but also in sponge-associated shrimp species (Duffy, 1996). Formation of host races may be the first stage of sympatric speciation (Maynard Smith, 1966; Berlocher, 1998). Isolation among host races is required for full speciation to occur, as the host races will revert to a panmictic population in absence of reproductive isolation (Jaenike, 1981). While the genetic divergence observed in the present study suggest some reproductive isolation, more analyses are needed to assess the degree of reproductive isolation between the two putative host races found within C. caribaea (Jaenike, 1981).

Mathematical models suggested that host-associated selective forces are critical for snails to specialize (Kawecki, 1996, 1997). The absence of host-associated genetic divergence within $C$. galea is therefore consistent with the results from earlier prey-preference experiments, where only a weak preference for the native host species was found (Hayes, 1990b). This is especially true for species whose pelagic larval stage is long, as a long larval stage favours generalists and promotes plasticity instead of divergence and speciation (Sotka, 2005). The larval ecology of snails is therefore relevant too. Larval development varies among coralliophillid species, with planktotrophic development being considered the plesiomorphic state within the Coralliophillinae, while some evidence indicates a prolonged intracapsular or lecithotrophic development in several species (Richter and Luque, 2002; Oliverio, 2008). Veliger shells of both C. galea and C. caribaea have been illustrated by Abbott (1958) and Wells and Lalli (1977) (only C. galea). Both species are thought to have planktotrophic development, but the duration of the planktonic stage remains unknown, and is expected to be $>30$ days for C. galea (Wells and Lalli, 1977; Richter and Luque, 2002; Johnston et al., 2012). Studies on the protoconch of snails may provide more insight in the larval ecology of Caribbean Coralliophila spp. (Oliverio, 2008).

For genetic divergence to be established, selection pressures must be strong enough to overcome homogenizing processes that increase gene flow between populations (Schluter, 2009; Johnston et al., 2012). The difference in host-associated genetic divergence between C. galea and C. caribaea suggests that selection pressures to specialize to either scleractinian or alcyonacean host species might be higher than the selection pressures to specialize to specific (groups of) species within these orders. Anti-predatory mechanisms of gorgonians might play a role here. Some generalist predators, such as the facultatively corallivorous polychaete Hermodice carunculata (Pallas, 1766), do feed on gorgonians (Marsden 1962; Preston and Preston 1975; Lasker 1985; Rotjan and Lewis 2008; Wolf et al., 2014), but most other species feeding on gorgonians, such as ovulid gastropods of the genus Cyphoma Röding, 1798, are specialized to this diet (Birkeland and Gregory 1975; Harvell and Suchanek 1987; Lasker and Coffroth, 1988; Lasker et al., 1988; Van Alstyne and Paul 1992; Burkepile and Hay, 2007; Chiappone et al., 2003; Reijnen et al., 2010; Schärer et al., 2010; Pinto et al., 2017; Reijnen and Van der Meij, 2017). Selection to overcome these mechanisms within C. caribaea might therefore have been strong enough to induce genetic divergence.

While specialization to (a group of) host species might have played a role in the intraspecific divergence observed within C. caribaea, the absence of a monophyletic Caribbean Coralliophila clade on the phylogenetic tree suggests that host-associated divergence was not the mechanism behind the divergence among species and that their common ancestor originated outside of the modern Caribbean. A similar pattern has been observed in the shrimp family Palaemonidae (Horká et al., 2016). Therefore, more extensive phylogenetic and phylogeographic analyses of Coralliophila spp. are needed to unravel the biogeographic patterns of this genus in the Caribbean.

The phylogenetic analyses in the present study suggest that the genus Coralliophila is polyphyletic, as $C$. caribaea seems to be closer related to the Indo-Pacific genus Leptoconchus than its own congeners (Fig. 15; Oliverio and Mariottini, 2001a; Oliverio et al., 2002, 2009). The genus Coralliophila is therefore in need of a taxonomic revision (Oliverio and Gofas, 2006; Oliverio, 2008; Oliverio et al., 2009).

Some overlap was observed between the distributions of intraspecific and interspecific divergence in the 
ABGD analysis, which is indicative of the absence of a universal threshold within the Coralliophilinae (Collins and Cruickshank, 2013). Only one other threshold value based on an ABGD analysis for muricid gastropods was found in literature: Barco et al. (2013) reported a threshold K2P distance between 0.020 and 0.025 based on a dataset of COI sequences of the genus Ocinebrina Jousseaume, 1880, which is lower than the value found in the present study. In addition, with the threshold value used in the present study, many of the Leptoconchus species included in the ABGD analysis could not be distinguished as separate species. This reinforces the lack of a universal threshold between intraspecific and interspecific divergence.

\section{Phenotypic plasticity and genetic differentiation}

While no host-associated genetic divergence has been observed within $C$. galea, adaptive genetic polymorphisms may still play a role, and the relative importance of both a genetic basis and phenotypic plasticity to variation in morphology remains unknown (Johnston et al., 2012). Both mechanisms are not mutually exclusive, as both genetic differentiation and phenotypic plasticity are thought to play a role in the adaptation of the snail Littorina saxatilis (Olivi, 1792) to the local habitat (Janson, 1983; Johannesson and Johannesson, 1996; Hollander et al., 2006). Reciprocal transplant experiments of $C$. galea among different host species showed that current host species was a more important determinant for growth than the native host species, suggesting that phenotypic plasticity plays at least some role in the morphological variation of $C$. galea (Baums et al., 2003b). Johnston et al. (2012) also attributed difference in growth rates at least partly to phenotypic plasticity. These results suggest that within C. galea, habitat-related phenotypic plasticity is more important than evolutionary divergence, although the intraspecific genetic variation observed within C. caribaea does not preclude a role for phenotypic plasticity within this species.

\section{Acknowledgements}

The first author would like to thank Dasha Wels and Thijs Böhm for being dive buddies and great company on Curaçao. Without them the fieldwork would not have been possible! Many thanks to Yee Wah Lau (Naturalis) for invaluable help with the phylogenetic analysis and identification of octocorals. Further thanks to Bastian Reijnen (Naturalis) for additional help with the phylogenetic part of this project. Elza Duijm (Naturalis) is acknowledged for performing the sequencing of the two markers for all the specimens. Also thanks to Katja Peijnenburg (Naturalis) for help with the morphometric analyses. Further acknowlegdements go to Dana Williams (University of Miami) for help with the determination of the sex of snails and Laureen Schenk (Substation Curaçao) for the logistics and permits for the dives on the Sea Aquarium reef. The staff of CARMABI Research Station staff is thanked for the hospitality and use of equipment and lab space during the stay on Curaçao. The A.M. Buitendijkfonds and the Jan-Joost ter Pelkwijkfonds are thanked for the financial contributions to the fieldwork. We are grateful to three anonymous reviewers for their constructive comments, which helped us to improve the manuscript considerably.

\section{References}

Abbott RT. 1958. Marine mollusks of Grand Cayman Island, British West Indies. Monographs of the Academy of Natural Sciences, Philadelphia 11: 1-138.

Adam H, Adams A. 1853. The genera of recent Mollusca arranged according to their organization. Vol. 1. J. van Voorst, London.

Adams DC, Otárola-Castillo E. 2013. Geomorph: an R package for the collection and analysis of geometric morphometric shape data. Methods in Ecology and Evolution 4: 393-399.

Adams DC, Collyer ML, Sherrat E. 2015. Geomorph: Software for geometric morphometric analyses. R package version 2.1.5. Available at: https://cran.r-project.org/web/packages/ geomorph/index.html

Altekar G, Dwarkadas S, Huelsenbeck JP, Ronquist F. 2004. Parallel Metropolis coupled Markov chain Monte Carlo for Bayesian phylogenetic inference. Bioinformatics 20: 407-415.

Anderson MJ. 2001. A new method for non-parametric multivariate analysis of variance. Austral Ecology 26: 32-46.

Appeltans W, Ahyong ST, Anderson G, Angel MV, Artois T, Bailly N, Bamber R, Barber A, Bartsch I, Berta A, BłazewiczPaszkowycz M, Bock P, Boxshall G, Boyko CB, Brandão SN, Bray RA, Bruce NL, Cairns SD, Chan T-Y, Cheng L, Collins AG, Cribb T, Curini-Galletti M, Dahdouh-Guebas F, Davie PJF, Dawson MN, De Clerck O, Decock W, De Grave S, de Voogd NJ, Domning DP, Emig CC, Erséus C, Eschmeyer W, Fauchald K, Fautin DG, Feist SW, Fransen CHJM, Furuya H, Garcia-Alvarez O, Gerken S, Gibson D, Gittenberger A, Gofas S, Gómez-Daglio L, Gordon DP, Guiry MD, Hernandez F, Hoeksema BW, Hopcroft RR, Jaume D, Kirk P, Koedam N, Koenemann S, Kolb JB, Kristensen RM, Kroh A, Lambert G, Lazarus DB, Lemaitre R, Longshaw M, Lowry J, Macpherson E, Madin LP, Mah C, Mapstone G, McLaughlin PA, Mees J, Meland K, Messing CG, Mills CE, Molodtsova TN, Mooi R, Neuhaus B, Ng PKL, Nielsen C, Norenburg J, Opresko DM, Osawa M, Paulay G, Perrin W, Pilger JF, Poore GCB, Pugh P, Read GB, Reimer JD, Rius M, Rocha RM, Saiz-Salinas JI, Scarabino V, Schierwater B, Schmidt-Rhaesa A, Schnabel KE, Schotte M, Schuchert P, Schwabe E, Segers H, Self-Sullivan C, Shenkar N, Siegel V, Sterrer W, Stöhr S, Swalla B, Tasker ML, Thuesen EV, Timm T, Todaro MA, Turon X, Tyler S, Uetz P, Van der Land J, Vanhoorne B, Van Ofwegen LP, Van Soest RWM, Vanaverbeke J, Walker-Smith G, Walter TC, Warren A, Williams GC, Wilson SP, Costello MJ. 2012. The magnitude of global marine species diversity. Current Biology 22: 2189-2202. 
Bandyopadhyay PK, Stevenson BJ, Ownby JP, Cady MT, Watkins M, Olivera BM. 2008. The mitochondrial genome of Conus textile, coxI-coxII intergenic sequences and Conoidean evolution. Molecular Phylogenetics and Evolution 46: 215-223.

Barco A, Claremont M, Reid DG, Houart R, Bouchet P, Williams ST, Cruaud C, Couloux A, Oliverio M. 2010. A molecular phylogenetic framework for the Muricidae, a diverse family of carnivorous gastropods. Molecular Phylogenetics and Evolution 56: 1025-1039.

Barco A, Houart R, Bonomolo G, Crocetta F, Oliverio M. 2013. Molecular data reveal cryptic lineages within the northeastern Atlantic and Mediterranean small mussel drills of the Ocinebrina edwardsii complex (Mollusca: Gastropoda: Muricidae). Zoological Journal of the Linnean Society 169: 389-407.

Barnes DJ. 1970. Locomotory response of Acanthaster planci to various species of coral. Nature 228: 342-343.

Baums I, Miller M, Szmant A. 2003a. Ecology of a corallivorous gastropod, Coralliophila abbreviata, on two scleractinian hosts. I: Population structure of snails and corals. Marine Biology 142: 1083-1091.

Baums I, Miller M, Szmant A. 2003b. Ecology of a corallivorous gastropod, Coralliophila abbreviata, on two scleractinian hosts. II. Feeding, respiration and growth. Marine Biology 142: 1093-1101.

Bayer FM. 1961. The shallow-water Octocorallia of the West Indian region. A manual for marine biologists. Martinus Nijhoff, The Hague.

Berlocher SH. 1998. Can sympatric speciation via host or habitat shift be proven from phylogenetic and biogeographic evidence? Pp. 99-113. In: Howard DJ, Berlocher SH, eds., Endless Forms: Species and Speciation. Oxford University Press, Oxford.

Berumen ML, Rotjan RD. 2010. New records of corallivory in the Red Sea. Coral Reefs 20: 727.

Birkeland C, Gregory B. 1975. Foraging behavior and rates of feeding of the gastropod, Cyphoma gibbosum. Science Bulletin of the Natural History Museum of Los Angeles County 20: 57-67.

Black R, Johnson MS. 1994. Growth rates in outbreak populations of the corallivorous gastropod Drupella cornus (Röding 1798) at Ningaloo Reef, Western Australia. Coral Reefs 13: 145-150.

Blaxter ML. 2004. The promise of a DNA taxonomy. Philosophical Transactions of the Royal Society of London B: Biological Sciences 359: 669-679.

Bouchet P. 2015. Coralliophila abbreviata. In: MolluscaBase (2015). Accessed through: World Register of Marine Species at http://www.marinespecies.org/aphia.php?p=taxdetails\&id $=759677$ on $2017-02-22$

Bouchet P, Warén A. 1985. Revision of the northeast Atlantic bathyal and abyssal Neogastropoda excluding Turridae (Mollusca, Gastropoda). Bolletino Malacologico, Supplemento 1: 1-296.

Boulding EG, Hay TK. 1993. Quantitative genetics of shell form of an intertidal snail: Constraints on short-term response to selection. Evolution 47: 576-592.

Born I. 1778. Index Rerum Naturalium Musei Caesarei Vindobonensis, Pars I. Testacea. Officina Krausiana, Vienna.

Brauer RW, Jordan MJ, Barnes DJ. 1970. Triggering of the stomach eversion reflex of Acanthaster planci by coral extracts. Nature 228: 344-346.
Brawley SH, Adey WH. 1982. Coralliophila abbreviata: A significant corallivore! Bulletin of Marine Science 32: 595-599.

Bruckner RJ, Bruckner AW, Williams Jr EH. 1997. Life history strategies of Coralliophila abbreviata Lamarck (Gastropoda: Coralliophilidae) on the southwest coast of Puerto Rico. Proceedings of the 8th International Coral Reef Symposium 1: 627-632.

Burkepile DE, Hay ME. 2007. Predator release of the gastropod Cyphoma gibbosum increases predation on gorgonian corals. Oecologia 154: 167-173.

Burridge AK, Goetze E, Raes N, Huisman J, Peijnenburg KTCA. 2015. Global biogeography and evolution of Cuvierina pteropods. BMC Evolutionary Biology 15: 39.

Calcara P. 1845. Cenno sui molluschi viventi e fossili della Sicilia da servire da supplimento ed insieme di critiche osservazioni all'opera di R.A. Philippi. Stamperia Reale, Palermo.

Cameron RAD, Carter MA. 1979. Intra- and interspecific effects of population density on growth and activity in some helicid land snails (Gastropoda: Pulmonata). Journal of Animal Ecology 48: 237-246.

Carvajal-Rodríguez A, Conde-Padín P, Rolán-Alvarex E. 2005. Decomposing shell form into size and shape by geometric morphometric methods in two sympatric ecotypes of Littorina saxatilis. Journal of Molluscan Studies 71: 313-318.

Chiappone M, Dienes H, Swanson DW, Miller SL. 2003. Density and gorgonian host-occupation patterns by flamingo tongue snails (Cyphoma gibbosum) in the Florida Keys. Caribbean Journal of Science 39: 116-127.

Chiu YW, Chen HC, Lee SC, Chen CA. 2002. Morphometric analysis of shell and operculum variations in the viviparid snail, Cipangopaludina chinensis (Mollusca: Gastropoda), in Taiwan. Zoological Studies 41: 321-330.

Claremont M, Reid DG, Williams ST. 2011. Evolution of corallivory in the gastropod genus Drupella. Coral Reefs 30: 977990.

Collins RA, Cruickshank RH. 2013. The seven deadly sins of DNA barcoding. Molecular Ecology Resources 13: 969-975.

Connell SD. 1998. Effects of predators on growth, mortality and abundance of a juvenile reef-fish: Evidence from manipulations of predator and prey abundance. Marine Ecology Progress Series 169: 251-261.

Cotton BC, Godfrey FK. 1932. South Australian shells. Part 3. South Australian Naturalist 13: 35-86.

Cotton PA, Rundle SD, Smith KE. 2004. Trait compensation in marine gastropods: Shell shape, avoidance behavior, and susceptibility to predation. Ecology 85: 1581-1584.

Dana JD. 1846. United States Exploring Expedition during the years 1838-1842. Zoophytes 7: 1-740. Lea and Blanchard, Philadelphia.

Darriba D, Taboada GL, Doallo R, Posada D. 2012. jModelTest 2: more models, new heuristics and parallel computing. $\mathrm{Na}$ ture Methods 9: 772-772.

De Jong KM, Coomans HE. 1988. Marine Gastropods from Curaçao, Aruba and Bonaire. Studies on the Fauna of Curaçao and other Caribbean Islands 69: 1-261.

Del Monaco C, Villamizar E, Narciso S. 2010. Selectividad de presas de Coralliophila abbreviata y C. caribaea en arrecifes coralinos del Parque Nacional Morrocoy, Venezuela: Una aproximacion experimental. Latin American Journal of Aquatic Research 38: 57-70. 
Dias TLP, Gondim AI. 2016. Bleaching in scleractinians, hydrocorals, and octocorals during thermal stress in a northeastern Brazilian reef. Marine Biodiversity 46: 303-307.

Dillwyn LW. 1823. Martini Lister Historia sive synopsis methodica conchyliorum, 3rd ed. E typographeo Clarendoniano, Oxford.

Duffy JE. 1996. Resource-associated population subdivision in a symbiotic coral-reef shrimp. Evolution 50: 360-373.

Ebling FJ, Kitching JA, Muntz L, Taylor CM. 1964. The ecology of Lough Ine. XIII. Experimental observations of the destruction of Mytilus edulis and Nucella lapillus by crabs. Journal of Animal Ecology 33: 73-82.

Ellis J, Solander D. 1786. The natural history of many curious and uncommon zoophytes, collected from various parts of the globe. Systematically arranged and described by the late Daniel Solander. Benjamin White and Son, London.

Feder JL, Chilcote CA, Bush GL. 1988. Genetic differentiation between sympatric host races of the apple maggot fly Rhagoletis pomonella. Nature 336: 61-64.

Fischer P. 1882. Diagnoses d'espèces nouvelles de mollusques recueillis dans le cours des expéditions scientifiques de l'aviso 'Le Travailleur' (1880 et 1881). Journal de Conchyliologie 30: 49-53.

Fisher R, O'Leary RA, Low-Choy S, Mengersen K, Knowlton N, Brainard RE, Caley MJ (2015) Species richness on coral reefs and the pursuit of convergent global estimates. Current Biology 25: 500-505.

Folmer O, Black M, Hoeh W, Lutz R, Vrijenhoek R. 1994. DNA primers for amplification of mitochondrial cytochrome $c$ oxidase subunit I from diverse metazoan invertebrates. $\mathrm{Mo}$ lecular Marine Biology and Biotechnology 3: 294-299.

Fraser DF, Gilliam J. 1992. Nonlethal impacts of predation invasion: Facultative suppression of growth and reproduction. Ecology 73: 959-970.

Gittenberger A, Gittenberger E. 2005. A hitherto unnoticed adaptive radiation: epitoniid species (Gastropoda : Epitoniidae) associated with corals (Scleractinia). Contributions to Zoology 74: 125-203.

Gittenberger A, Gittenberger E. 2011. Cryptic, adaptive radiation of endoparasitic snails: Sibling species of Leptoconchus (Gastropoda: Coralliophilidae) in corals. Organisms Diversity and Evolution 11: 21-41.

Gittenberger A, Hoeksema BW. 2013. Habitat preferences of coral-associated wentletrap snails (Gastropoda: Epitoniidae). Contributions to Zoology 82: 1-25.

Glynn PW, Krupp DA. 1986. Feeding biology of a Hawaiian sea star corallivore, Culcita novaeguineae Muller \& Troschel. Journal of Experimental Marine Biology and Ecology 96: 75-96.

Gochfeld DJ. 2004. Predation-induced morphological and behavioral defenses in a hard coral: Implications for foraging behavior of coral-feeding butterflyfishes. Marine Ecology Progress Series 267: 145-158.

Gofas S. 2005. Coralliophila fontanangioyae Smriglio \& Mariottini, 2000. In: MolluscaBase (2016). Accessed through: World Register of Marine Species at http://www.marinespecies.org/aphia.php? $\mathrm{p}=$ taxdetails\&id $=181046$ on 201702-22

Goldberg WM. 1971. A note on the feeding behavior of the snapping shrimp Synalpheus fritzmuelleri Coutière (Decapoda, Alpheidae). Crustaceana 21: 318-320.
Goodall C. 1991. Procrustes methods in the statistical analysis of shape. Journal of the Royal Statistical Society B 53: 285-339.

Gower JC. 1975. Generalized procrustes analysis. Psychometrika 40: 33-51.

Gregory JW. 1895. Contributions to the palaeontology and physical geology of the West Indies. Quarterly Journal of the Geological Society of London 51: 255-312.

Harasewych MG, Adamkewicz SL, Blake JA, Saudek D, Spriggs T, Bult CJ. 1997. Neogastropod phylogeny: a molecular perspective. Journal of Molluscan Studies 63: 327-351.

Harvell CD, Fenical W. 1989. Chemical and structural defenses of Caribbean gorgonians (Pseudopterogorgia spp.): Intercolony localization of defense. Limnology and Oceanography 34: 382-389.

Harvell CD, Suchanek T. 1987. Partial predation on tropical gorgonians by Cyphoma gibbosum (Gastropoda). Marine Ecology Progress Series 38: 37-44.

Harvell CD, Fenical W, Greene CH. 1988. Chemical and structural defenses of Caribbean gorgonians (Pseudopterogorgia spp.). I. Development of an in situ feeding assay. Marine Ecology Progress Series 49: 287-294.

Hasegawa M, Kishino H, Yano T. 1985. Dating of the humanape splitting by a molecular clock of mitochondrial DNA. Journal of Molecular Evolution 22: 160-174.

Hayes JA. 1990a. Distribution, movement and impact of the corallivorous gastropod Coralliophila abbreviata (Lamarck) on a Panamánian patch reef. Journal of Experimental Marine Biology and Ecology 142: 25-42.

Hayes JA. 1990b. Prey preference in a Caribbean corallivore, Coralliophila abbreviata (Lamarck) (Gastropoda, Coralliophilidae). Bulletin of Marine Science 47: 557-560.

Hoeksema BW, Ten Hove H. 2017. The invasive sun coral Tubastraea coccinea hosting a native Christmas tree worm at Curaçao, Dutch Caribbean. Marine Biodiversity 47: 59-65.

Hoeksema BW, Van der Meij SET, Fransen CHJM. 2012. The mushroom coral as a habitat. Journal of the Marine Biological Association of the United Kingdom 92: 647-663.

Hoeksema BW, Scott CM, True JD. 2013. Dietary shift in corallivorous Drupella snails following a major bleaching event at Koh Tao, Gulf of Thailand. Coral Reefs 32: 423-428.

Hoeksema BW, Lau YW, Ten Hove H. 2015. Octocorals as secondary hosts for Christmas tree worms off Curaçao. Bulletin of Marine Science 91: 489-490.

Hoeksema BW, van Beusekom M, Ten Hove HA, Ivanenko VN, Van der Meij SET, van Moorsel GWNM. 2017. Helioseris cucullata as a host coral at St. Eustatius, Dutch Caribbean. Marine Biodiversity 47: 71-78.

Hollander J, Collyer ML, Adams DC, Johannesson K. 2006. Phenotypic plasticity in two marine snails: Constraints superseding life history. Journal of Evolutionary Biology 19: 1861-1872.

Horká I, De Grave S, Fransen CHJM, Petrusek A, Ďuriš Z. 2016. Multiple host switching events shape the evolution of symbiotic palaemonid shrimps (Crustacea: Decapoda). Scientific Reports 6: 26486.

Houttuyn M. 1772. Natuurlyke historie of uitvoerige beschryving der dieren, planten en mineraalen, volgens het samenstel van den heer Linnaeus met naauwkeurige afdeelingen. Houttuyn, Amsterdam.

Jaenike J. 1981. Criteria for ascertaining the existence of host races. The American Naturalist 117: 830-834. 
Janson K. 1983. Selection and migration in two distinct phenotypes of Littorina saxatilis in Sweden. Oecologia 59: 5861.

Johannesson B, Johannesson K. 1996. Population differences in behaviour and morphology in the snail Littorina saxatilis: Phenotypic plasticity or genetic differentiation? Journal of Zoology 240: 475-493.

Johnston L, Miller MW. 2006. Variation in life-history traits of the corallivorous gastropod Coralliophila abbreviata on three coral hosts. Marine Biology 150: 1215-1225.

Johnston L, Miller MW, Baums IB. 2012. Assessment of hostassociated genetic differentiation among phenotypically divergent populations of a coral-eating gastropod across the Caribbean. PloS ONE 7: e47630.

Jousseaume FP. 1880. Division méthodique de la famille des Purpuridés. Le Naturaliste 2 : 335-338.

Katoh K, Kuma KI, Toh H, Miyata T. 2005. MAFFT version 5: Improvement in accuracy of multiple sequence alignment. Nucleic Acids Research 33: 511-518.

Kawecki TJ. 1996. Sympatric speciation driven by beneficial mutations. Proceedings of the Royal Society B: Biological Sciences 263: 1515-1520.

Kawecki TJ. 1997. Sympatric speciation via habitat specialization driven by deleterious mutations. Evolution 51: 1751-1763.

Kemp P, Bertness MD. 1984. Snail shape and growth rates: Evidence for plastic shell allometry in Littorina littorea. Proceedings of the National Academy of Sciences of the United States of America 81: 811-813.

Kimura M. 1980. A simple method for estimating evolutionary rates of base substitutions through comparative studies of nucleotide sequences. Journal of Molecular Evolution 16: 111120.

Kitching JA, Muntz L, Ebling FJ. 1966. The Ecology of Lough Ine. XV. The ecological significance of shell and body forms in Nucella. Journal of Animal Ecology 35: 113-126.

Knowlton N, Lang JC, Keller BD. 1988. Fates of staghorn coral isolates on hurricane-damaged reefs in Jamaica: The role of predators. Proceedings of the 6th International Coral Reef Symposium 2: 83-88.

Knowlton N, Lang JC, Keller BD. 1990. Case study of natural population collapse: Post-hurricane predation on Jamaican staghorn corals. Smithsonian Contributions to the Marine Sciences 31: 1-25.

Kružić P, Sršen P, Cetinić K, Zavodnik D. 2013. Coral tissue mortality of the coral Cladocora caespitosa caused by gastropod Coralliophila meyendorffi in the Mljet National Park (eastern Adriatic Sea). Journal of the Marine Biological Association of the United Kingdom 93: 2101-2108.

Lages BG, Fleury BG, Pinto AC, Creed JC. 2010. Chemical defenses against generalist fish predators and fouling organisms in two invasive ahermatypic corals in the genus Tubastraea. Marine Ecology 31: 473-482.

Lamarck JBP. 1816. Histoire naturelle des animaux sans vertèbres. Vol. 2. Verdier, Paris.

Lasker HR. 1985. Prey preferences and browsing pressure of the butterflyfish Chaetodon capistratus on Caribbean gorgonians. Marine Ecology Progress Series 21: 213-220.

Lasker HR, Coffroth MA. 1988. Temporal and spatial variability among grazers: variability in the distribution of the gastropod Cyphoma gibbosum on octocorals. Marine Ecology Progress Series 43: 285-295.
Lasker HR, Coffroth MA, Fitzgerald LM. 1988. Foraging patterns of Cyphoma gibbosum on octocorals: The roles of host choice and feeding preference. The Biological Bulletin 174: 254-266.

Lau YW. 2016. Octocorals of St. Eustatius. In: Hoeksema BW, ed., Marine biodiversity survey of St. Eustatius, Dutch Caribbean, 2015. Naturalis Biodiversity Center, Leiden and ANEMOON Foundation, Bennebroek, The Netherlands pp. 38-42.

Le Sueur CA. 1820. Description de plusiers animaux appartenant aux polypiers lamellifères de M. le Chev. Lamarck. Mémoires du Muséum d'Histoire Naturelle 7: 271-298.

Liew T-S, Schilthuizen M. 2016. A method for quantifying, visualising, and analysing gastropod shell form. PLOS ONE 11(6): e0157069.

Linnaeus C. 1758. Systema naturae per regna tria naturae, secundum classes, ordines, genera, species, cum characteribus, differentiis, synonymis, locis. Editio decima, reformata. Laurentius Salvius, Holmiae.

Linnaeus C. 1767. Systema naturae per regna tria naturae: secundum classes, ordines, genera, species, cum characteribus, differentiis, synonymis, locis. Editio duodecima. Laurentius Salvius, Holmiae.

Locke JM, Weil E, Coates KA. 2007. A newly documented species of Madracis (Scleractinia: Pocilloporidae) from the Caribbean. Proceedings of the Biological Society of Washington 120: $214-226$.

Mariani S, Peijnenburg KTCA, Weetman D. 2012. Independence of neutral and adaptive divergence in a low dispersal marine mollusc. Marine Ecology Progress Series 446: 173-187.

Marsden JR. 1962. A coral-eating polychaete. Nature 193: 598.

Martin D, Gil J, Abgarian C, Evans E, Turner Jr. EM, Nygren A. 2014. Coralliophila from Grand Cayman: Specialized coral predator or parasite? Coral Reefs 33: 1017.

Maynard Smith J. 1966. Sympatric speciation. The American Naturalist 100: 637-650.

McClanahan TR. 1997. Dynamics of Drupella cornus populations on Kenyan coral reefs. Proceedings of the 8th International Coral Reef Symposium 1: 633-638.

McPheron BA, Smith DC, Berlocher SH. 1988. Genetic differences between host races of Rhagoletis pomonella. Nature 336: 64-66.

Miller AC. 1981. Cnidarian prey of the snails Coralliophila abbreviata and C. caribaea (Gastropoda: Muricidae) in Discovery Bay, Jamaica. Bulletin of Marine Science 31: 932-934.

Milne Edwards H, Haime J. 1849. Mémoire sur les polypiers appartenant a la famille des Oculinides, au groupe intermediate des Pseudoastréides et a la famille des Fongides. Comptes Rendus Hebdomadaires des Séances de l'Académie des Sciences 29: 67-73.

Milne Edwards H, Haime J. 1851. Recherches sur les polypiers. Mémoire 6. Monographie des Fongides. Annales des Sciences Naturelles, Zoologie, Series 3 15: 73-144.

Mitteroecker P, Gunz P, Bernhard M, Schaefer K, Bookstein FL. 2004. Comparison of cranial ontogenetic trajectories among great apes and humans. Journal of Human Evolution 46: 679-698.

Moerland MS, Scott CM, Hoeksema BW. 2016. Prey selection of corallivorous muricids at Koh Tao (Gulf of Thailand) four years after a major coral bleaching event. Contributions to Zoology 85: 291-309. 
Netchy K, Hallock P, Lunz KS, Daly KL. 2016. Epibenthic mobile invertebrate diversity organized by coral habitat in Florida. Marine Biodiversity 46: 451-463.

Moore RJ, Huxley CJ. 1976. Aversive behaviour of crown-ofthorns starfish to coral evoked by food-related chemicals. Nature 263: 407-409.

Nakaoka M. 2000. Nonlethal effects of predators on prey populations: Predator-mediated change in bivalve growth. Ecology 81: 1031-1045.

Nylander JAA. 2004. MrModeltest v2. Program distributed by the author. Evolutionary Biology Centre, Uppsala University.

O'Neal W, Pawlik JR. 2002. A reappraisal of the chemical and physical defenses of Caribbean gorgonian corals against predatory fishes. Marine Ecology Progress Series 240: 117-126.

Oliverio M. 2008. Coralliophilinae (Neogastropoda: Muricidae) from the southwest Pacific. In: Héros V, Cowie RH, Bouchet P, eds., Tropical Deep-Sea Benthos 25. Mémoires du Muséum National d'Histoire Naturelle 196: 481-585.

Oliverio M, Gofas S. 2006. Coralliophiline diversity at mid-Atlantic seamounts (Neogastropoda, Muricidae, Coralliophlinae). Bulletin of Marine Science 79: 205-230.

Oliverio M, Mariottini P. 2001a. A molecular framework for the phylogeny of Coralliophila and related muricoids. Journal of Molluscan Studies 67: 215-224.

Oliverio M, Mariottini P. 2001b. Contrasting morphological and molecular variation in Coralliophila meyendorffii (Muricidae, Coralliophilinae). Journal of Molluscan Studies 67: 243-245.

Oliverio M, Cervelli M, Mariottini P. 2002. ITS2 rRNA evolution and its congruence with the phylogeny of muricid neogastropods (Caenogastropoda, Muricoidea). Molecular Phylogenetics and Evolution 25: 63-69.

Oliverio M, Barco A, Richter A, Modica M V. 2009. The coralliophiline (Gastropoda: Muricidae) radiation: Repeated colonizations of the deep sea? Nautilus 123: 113-120.

Olivi G. 1792. Zoologia Adriatica, ossia catalogo ragionato degli animali del golfo e della lagune di Venezia. Bassano.

Oren U, Brickner I, Loya Y. 1998. Prudent sessile feeding by the corallivore snail, Coralliophila violacea on coral energy sinks. Proceedings of the Royal Society B: Biological Sciences 265: 2043-2050.

Ott B, Lewis JB. 1972. The importance of the gastropod Coralliophila abbreviata (Lamarck) and the polychaete Hermodice carunculata (Pallas) as coral reef predators. Canadian Journal of Zoology 50: 1651-1656.

Pallas PS. 1766. Miscellanea zoologica. Quibus novae imprimis atque obscurae animalium species describuntur et observationibus iconibusque illustrantur. Petrum van Cleef. Hagí Comitum.

Paradis E. 2010. pegas: An R package for population genetics with an integrated-modular approach. Bioinformatics 26: 419-420.

Paradis E, Claude J, Strimmer K. 2004. APE: Analyses of phylogenetics and evolution in R language. Bioinformatics 20: 289-290.

Pawlik JR. 1993. Marine invertebrate chemical defenses. Chemical Reviews 93: 1911-1922.

Pawlik JR, Burch MT, Fenical W. 1987. Patterns of chemical defense among Caribbean gorgonian corals: a preliminary survey. Journal of Experimental Marine Biology and Ecology 108: 55-66.
Petuch EJ. 1987. New Caribbean molluscan faunas. Coastal Education \& Research Foundation, Charlottesville.

Petuch EJ, Myers RF. 2014. Molluscan communities of the Florida Keys and adjacent areas: Their ecology and biodiversity. CRC Press, Boca Raton, FL.

Pinto TK, Benevides LJ, Sampaio CLS. 2017. Cyphoma macumba Petuch 1979 (Gastropoda: Ovulidae): a versatile predator of the Brazilian Octocorallia. Marine Biodiversity 47: 165166.

Plaisance L, Caley MJ, Brainard RE, Knowlton N. 2011. The diversity of coral reefs: What are we missing? PLOS ONE 6: e25026.

Pons-Moya J, Pons GX, Collado M. 2001. Els Coralliophilidae (Mollusca: Gastropoda) de les Illes Balears: primera cita de Latiaxis sentix (Bayer, 1971), L. amaliae (Kobelt, 1907) i Coralliophila brevis (Blainville, 1832). Bolletí Societat d'Història Natural de les Balears 44: 67-71.

Potkamp G, Vermeij MJA, Hoeksema BW. 2017. Host-dependent variation in density of corallivorous snails (Coralliophila spp.) at Curaçao, southern Caribbean. Marine Biodiversity 47: 91-99.

Powell THQ, Forbes AA, Hood GR, Feder JL. 2014. Ecological adaptation and reproductive isolation in sympatry: Genetic and phenotypic evidence for native host races of Rhagoletis pomonella. Molecular Ecology 23: 688-704.

Preston EM, Preston JL. 1975. Ecological structure in a West Indian gorgonian fauna. Bulletin of Marine Science 25: 248-258.

Puillandre N, Lambert A, Brouillet S, Achaz G. 2012. ABGD, Automatic Barcode Gap Discovery for primary species delimitation. Molecular Ecology 21: 1864-1877.

Puillandre N, Strong EE, Bouchet P, Boisselier M-C, Couloux A, Samadi S. 2009. Identifying gastropod spawn from DNA barcodes: Possible but not yet practicable. Molecular Ecology Resources 9: 1311-1321.

Queiroga H, Costa R, Leonardo N, Soares D, Cleary DFR. 2011. Morphometric variation in two intertidal littorinid gastropods. Contributions to Zoology 80: 201-211.

R Core Team. 2015. R: A language and environment for statistical computing.

Reaka-Kudla ML. 1997. The global biodiversity of coral reefs: a comparision with rain forests. Pp. 83-108 in: Reaka-Kudla ML, Wilson DE, Wilson EO eds., Biodiversity II: Understanding and protecting our biological resources. Joseph Henry Press, Washington, DC.

Reijnen BT, Van der Meij SET. 2017. Coat of many colours DNA reveals polymorphism of mantle patterns and colouration in Caribbean Cyphoma Röding, 1798 (Gastropoda, Ovulidae). PeerJ 5: e3018.

Reijnen BT, Hoeksema BW, Gittenberger E. 2010. Host specificity and phylogenetic relationships among Atlantic Ovulidae (Mollusca: Gastropoda). Contributions to Zoology 79: 69-78.

Richter A, Luque ÁA. 2002. Current knowledge on Coralliophilidae (Gastropoda) and phylogenetic implication of anatomical and reproductive characteres. Bollettino Malacologico 38: 5-18.

Richter A, Luque ÁA. 2004. Sex change in two Mediterranean species of Coralliophilidae (Mollusca: Gastropoda: Neogastropoda). Journal of the Marine Biological Association of the UK 84: 383-392. 
Risso A. 1826. Histoire naturelle des principales productions de l'Europe méridionale et particulièrement de celles des environs de Nice et des Alpes Maritimes. Vol. 5. Paris, FG Levrault Libraire.

Robertson R. 1970. Review of the predators and parasites of stony corals, with special reference to symbiotic prosobranch gastropods. Pacific Science 24: 43-54.

Röding PF. 1798. Museum Boltenianum, sive catalogus cimeliorum e tribus regnis naturae olim collegerat Joa. Fried. Bolten, M.D.p.d. Pars Secunda. Hamburg, Typis Johan. Christi.

Rohlf F, Slice D. 1990. Extensions of the Procrustes method for the optimal superimposition of landmarks. Systematic Biology 39: 40-59.

Ronquist F, Teslenko M, Mark P van der, Ayres DL, Darling A, Höhna S, Larget B, Liu L, Suchard MA, Huelsenbeck JP. 2012. Mrbayes 3.2: Efficient bayesian phylogenetic inference and model choice across a large model space. Systematic Biology 61: 539-542.

Rotjan RD, Lewis SM. 2008. Impact of coral predators on tropical reefs. Marine Ecology Progress Series 367: 73-91.

Rüppell E. 1834. Description of a new genus of pectinibranchiated gasteropodous Mollusca (Leptoconchus). Proceedings of the Zoological Society of London 1834: 105-106.

Sánchez JA, Zea S, Díaz JM. 1998. Patterns of octocoral and black coral distribution in the oceanic barrier reef-complex of Providencia island, southwestern Caribbean. Caribbean Journal of Science 34: 250-264.

Sánchez JA, McFadden CS, France SC, Lasker HR. 2003. Molecular phylogenetic analyses of shallow-water Caribbean octocorals. Marine Biology 142: 975-987.

Sánchez JA, Fuentes-Pardo AP, Almhain ÍN, Ardila-Espitia NE, Cantera-Kintz J, Forero-Shelton M. 2016. The masquerade game: marine mimicry adaptation between egg-cowries and octocorals. PeerJ 4: e2051.

Schärer MT, Nemeth MI. 2010. Mass mortality of gorgonians due to a Cyphoma gibbosum (Linnaeus) population outbreaks at Mona Island, Puerto Rico. Coral Reefs 29: 533.

Schembri P, Dimech M, Camilleri M, Page R. 2007. Living deep-water Lophelia and Madrepora corals in Maltese waters (Strait of Sicily, Mediterranean Sea). Cahiers de Biologie Marine 48: 77-83.

Schiaparelli S, Barucca M, Olmo E, Boyer M, Canapa A. 2005. Phylogenetic relationships within Ovulidae (Gastropoda: Cypraeoidea) based on molecular data from the 16S rRNA gene. Marine Biology 147: 411-420.

Schluter D. 2009. Evidence for ecological speciation and its alternative. Science 323: 737-741.

Schoepf V, Herler J, Zuschin M. 2010. Microhabitat use and prey selection of the coral-feeding snail Drupella cornus in the northern Red Sea. Hydrobiologia 641: 45-57.

Scott PJB. 1987. Associations between corals and macro-infaunal invertebrates in Jamaica, with a list of Caribbean and Atlantic coral associates. Bulletin of Marine Science 40: 271-286.

Scott CM, Mehrotra R, Hein MY, Moerland MS, Hoeksema BW. 2017. Population dynamics of corallivores (Drupella and Acanthaster) on coral reefs of Koh Tao, a diving destination in the Gulf of Thailand. Raffles Bulletin of Zoology 65: 68-79.

Sharp WC, Delgado GA. 2015. Predator-prey interactions between the corallivorous snail Coralliophila abbreviata and the Carnivorous deltoid rock snail Thais deltoidea. The Biological Bulletin 229: 129-133.
Sela I, Ashkenazy H, Katoh K, Pupko T. 2015. GUIDANCE2: accurate detection of unreliable alignment regions accounting for the uncertainty of multiple parameters. Nucleic Acids Research 43: W7-W14.

Smiriglio C, Mariottini P. 2000. Description of three new Coralliophilidae from the Eastern Atlantic ocean. La Conchiglia 296: $11-18$

Sotka EE. 2005. Local adaptation in host use among marine invertebrates. Ecology Letters 8: 448-459.

Stella JS, Jones GP, Pratchett MS. 2010. Variation in the structure of epifaunal invertebrate assemblages among coral hosts. Coral Reefs 29: 957-973.

Stella JS, Pratchett MS, Hutchings PA, Jones GP. 2011. Coralassociated invertebrates: diversity, ecological importance and vulnerability to disturbance. Oceanography and Marine Biology: an Annual Review 49: 43-104.

Stone JR. 1998. Landmark-based thin-plate spline relative warp analysis of gastropod shells. Systematic Biology 47: 254-263.

Szmant AM, Ferrer LM, FitzGerald LM. 1990. Nitrogen excretion and O:N ratios in reef corals: Evidence for conservation of nitrogen. Marine Biology 104: 119-127.

Tavaré S. 1986. Some probabilistic and statistical problems in the analysis of DNA sequences. American Mathematical Society: Lectures on Mathematics in the Life Sciences 17: 57-86.

Taviani M, Angeletti L, Dimech M, Mifsud C, Oliverio M. 2008. The construction of deep-water coral ecosystem biodiversity in the Mediterranean basin: hints from dwc obligatory gastropods predators. Poster HERMES $3^{\text {rd }}$ Annual Meeting.

Taviani M, Angeletti L, Dimech M, Mifsud C, Freiwald A, Harasewych MG, Oliverio M. 2009. Coralliophilinae (Gastropoda: Muricidae) associated with deep-water coral banks in the Mediterranean. Nautilus 123: 106-112.

Urdy S, Goudemand N, Bucher H, Chirat R. 2010a. Allometries and the morphogenesis of the molluscan shell: A quantitative and theoretical model. Journal of Experimental Zoology Part B: Molecular and Developmental Evolution 314B: 280302.

Urdy S, Goudemand N, Bucher H, Chirat R. 2010b. Growth-dependent phenotypic variation of molluscan shells: Implications for allometric data interpretation. Journal of Experimental Zoology Part B: Molecular and Developmental Evolution 314B: 303-326.

Van Alstyne KL, Paul VJ. 1992. Chemical and structural defenses in the sea fan Gorgonia ventalina: effects against generalist and specialist predators. Coral Reefs 11: 155-159.

Van der Meij SET. 2014. Host species, range extensions, and an observation of the mating system of Atlantic shallow-water gall crabs (Decapoda: Cryptochiridae). Bulletin of Marine Science 90: 1001-1010.

Vermeij GJ. 1974. Marine faunal dominance and molluscan shell form. Evolution 28: 656-664.

Vermeij GJ. 1993. A natural history of shells. Princeton University Press, Princeton.

Vermeij MJA. 2010. First observation of a nocturnal nudibranch feeding on Caribbean corals. Coral Reefs 29: 1047.

Verrill AE, 1901. Variations and nomenclature of the Bermudian, West Indian and Brazilian reef corals, with notes on various Indo-Pacific corals. Transactions of the Connecticut Acadedmy of Arts and Sciences 11: 63-206. 
Ward J. 1965. The digestive tract and its relation to feeding habits in the Stenoglossan prosobranch Coralliophila $a b$ breviata (Lamark). Canadian Journal of Zoology 43: 447464.

Wells FE, Lalli CM. 1977. Reproduction and brood protection in the gastropods Coralliophila abbreviata and C. caribaea. Journal of Molluscan Studies 43: 79-87.

Wells JW. 1973. New and old scleractinian corals from Jamaica. Bulletin of Marine Science 23: 16-58.

Williamson P, Cameron RAD, Carter MA. 1976. Population density affecting adult shell size of snail Cepaea nemoralis L. Nature 263: 496-497.
Wolf AT, Nugues MM, Wild C. 2014. Distribution, food preference, and trophic position of the corallivorous fireworm $\mathrm{Her}$ modice carunculata in a Caribbean coral reef. Coral Reefs 33: 1153-1163.

Zelditch ML, Swiderski DL, Sheets HD, Fink WL. 2004. Geometric morphometrics for biologists. Elsevier Academic Press, San Diego and London.

Received: 29 June 2016

Revised and accepted: 17 March 2017

Published online: 8 June 2017

Editor: Danwei Huang

\section{Online Supplementary Material}

1. Methods used to calculate replication error in landmark data.

2. Hypothetical example of analyses of allometric patterns.

3. Table S1 with previously published sequences included in the Automated Barcode Gap Discovery analysis.

4. Tables S2-S7 with pairwise statistics for morphometric analyses.

5. Figs. S1-S2 with phylogenetic trees constructed for $12 \mathrm{~S}$ and COI separately. 


\section{Appendix}

\section{Systematics of Coralliophila spp. at Curaçao}

In this appendix, a formal description of Coralliophila curacaoensis sp. nov. is presented, together with diagnostic descriptions of two common congeners occurring in Curaçao: C. caribaea Abbott, 1958 and C. galea (Dillwyn, 1823) (see also De Jong and Coomans 1988).

\section{Systematics}

Family Muricidae Rafinesque, 1815.

Subfamily Coralliophilinae Chenu, 1859

Genus Coralliophila Adams and Adams, 1853

For description and synonymy, see Oliverio (2008: 485). The genus Coralliophila, with which C. curacaoensis sp. nov. has been classified, is used here in a wide sense (Coralliophila s.l.), as strong evidence exists for polyphyly within this genus as currently defined (Oliverio and Mariottini, 2001a; Oliverio et al. 2002, 2009; Oliverio 2008). A taxonomic revision of the genus, limiting its use only to the clade that includes the Indo-Pacific type species Coralliophila violacea (Kiener, 1836), might classify the other species into a separate genus.

\section{Coralliophila caribaea Abbott, 1958}

Fig. 18.

Diagnosis. Shell angular, rhomboidal in shape. High conical spire, sutures incised. Aperture oval. Teleoconch sculptured with spiral cords, densely packed with small scales. On the body whorl, higher and lower spiral cords set alternately. Six to seven axial ribs per whorl. Umbilical area moderately narrow, fasciole imbricated, umbilical furrow closed. Colouration operculum deep red to violet. Associated with alcyonacean and scleractinian host species. Also recorded from zoantharians and coralliomorpharians (Miller, 1981).

\section{Coralliophila galea (Dillwyn, 1823)}

Fig. 19.

Synonym. Coralliophila abbreviata auct. non Lamarck, 1816 (see Bouchet, 2015)

Diagnosis. Globose, inflated shell. Short conical spire, sutures not incised. Aperture oval, wide. Teleoconch sculptured with numerous low spiral cords, densely packed with small scales. One larger spiral cord on the body whorl, located close to the anterior end of the shell. Umbilical area wide, with imbricated fasciole and open umbilical furrow. Yellow to transparent operculum. Associated with a range of scleractinian host species. Also recorded from Zoantharia and Coralliomorpharia (Miller, 1981).

\section{Coralliophila curacaoensis sp. nov. Potkamp and} Hoeksema

Fig. 20.

urn:1sid:zoobank.org:act:E442DA0F-9473-44BDA181-E4869324FFA0

Etymology. Named after the island of Curaçao, the type locality of $C$. curacaoensis sp. nov.

Type material. Holotype RMNH.5004326 (Figs. 20a-f) and nine paratypes RMNH.5004323-5004325 (only molecular sequences deposited), RMNH.50043275004328, RMNH.5004329-5004332 (only soft tissue deposited) (Figs. 20g-y).

Type locality. Leeward coast of Curaçao, Playa Daaibooi, $12^{\circ} 13^{\prime} \mathrm{N}, 69^{\circ} 05^{\prime} \mathrm{W}, 11 \mathrm{~m}$ depth (holotype RMNH.5004326 and paratypes RMNH.5004323 and RMNH.5004327-5004332). Playa Kalki, $12^{\circ} 22^{\prime} \mathrm{N}$, $69^{\circ} 09^{\prime} \mathrm{W}, 8 \mathrm{~m}$ depth (paratype RMNH.5004324) and 10 m depth (paratype RMNH.5004325).

Distribution. Only recorded from the type locality, Curaçao, southern Caribbean. Specimens were found in association with corals of the scleractinian species Madracis auretenra Locke, Weil and Coates, 2007.

Diagnosis. Small size, shell angular, rhomboidal in shape. Aperture oval, elongated. Cone-shaped spire with incised sutures. Teleoconch sculptured with spiral cords, on the body whorl relatively high and widely set. Two high imbricated spiral cords around the shoulder, spiral cords decreasing in size towards the anterior end. Eight to nine varices per whorl, giving the shell a latticed appearance. Umbilical area moderately wide, with imbricate fasciole and narrowly open umbilical furrow. Operculum transparent to pale red.

Description. Small shell size compared to its congeners: largest specimen with a length of $8.9 \mathrm{~mm}$, width $5.8 \mathrm{~mm}$. Shell rhomboidal in shape with teleoconch consisting of 3+ whorls. Protoconch eroded on holotype. Spire cone-shaped, sides angular to almost flat, sutures moderately incised. Body whorl more than half 


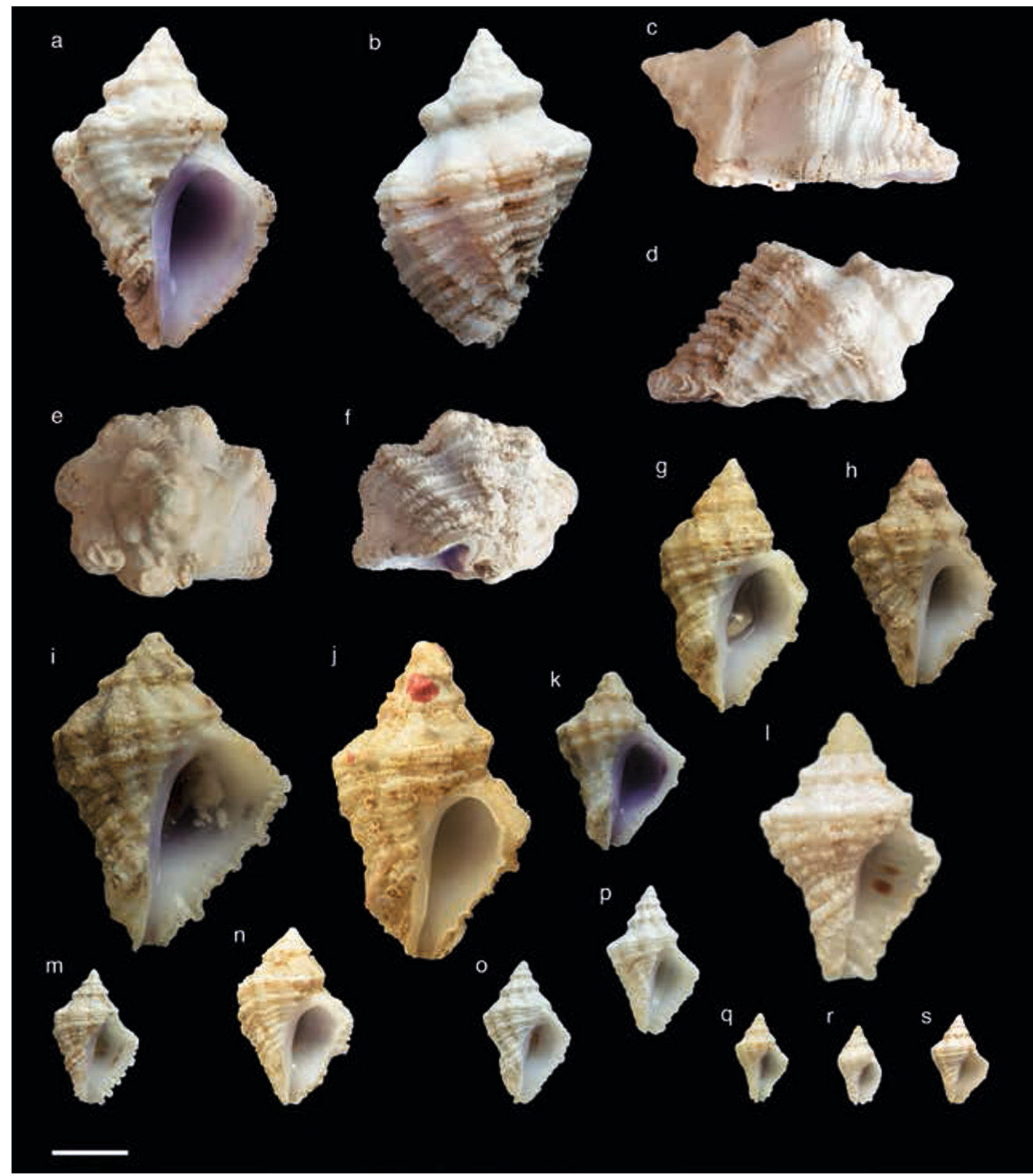

Fig. 18. Coralliophila caribaea. Ventral, dorsal, both lateral, posterior and anterior views of a single shell, respectively (a-f). Examples of intraspecific variation in shell size and shape (g-s). An egg capsule is visible in one shell aperture (g). Scale bar: $1 \mathrm{~cm}$. 


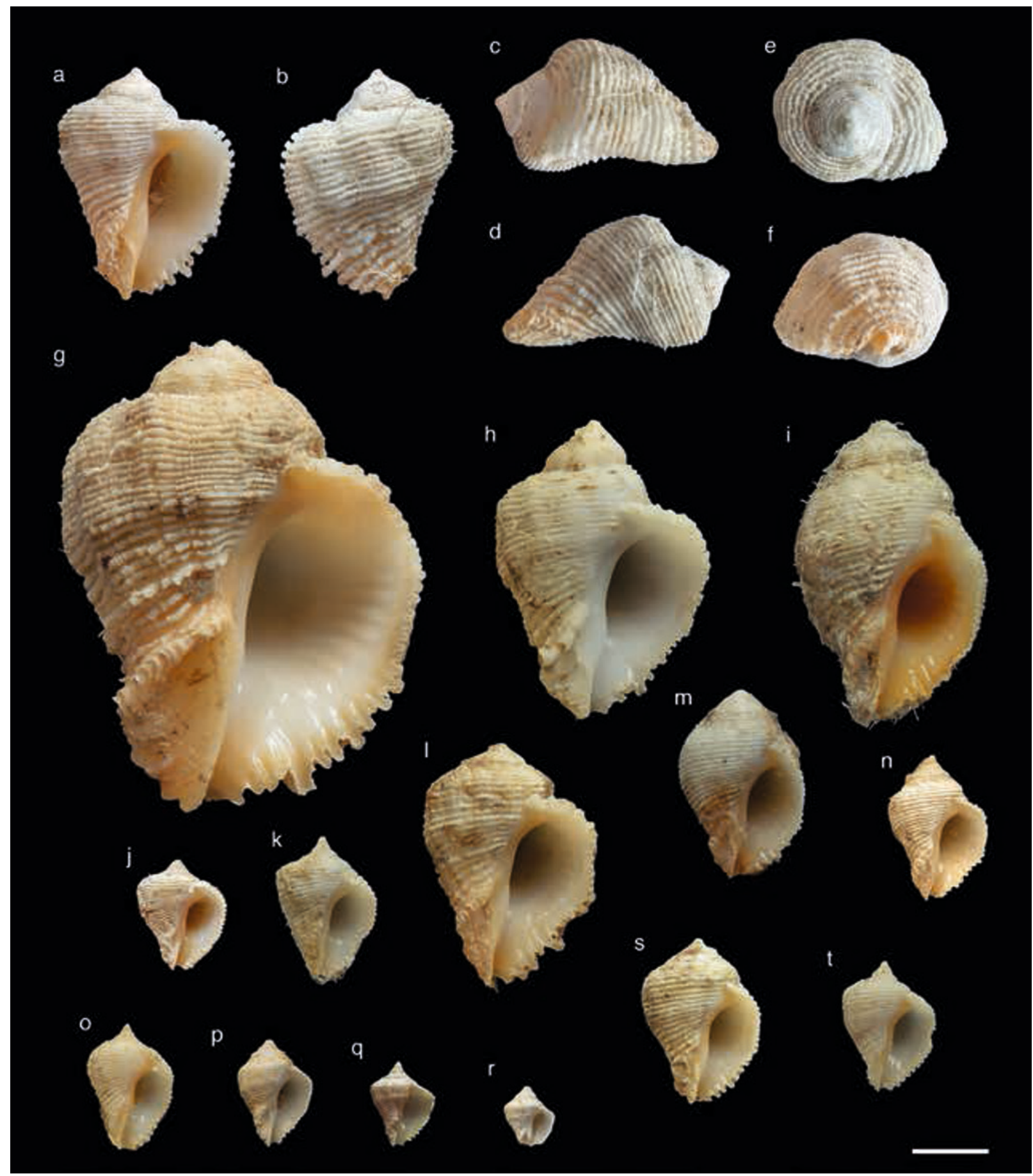

Fig. 19. Coralliophila galea. Ventral, dorsal, lateral, posterior and the anterior views of a single shell, respectively (a-f). Examples of intraspecific variation in shell size and shape $(\mathrm{g}-\mathrm{q})$. Scale bar: $1 \mathrm{~cm}$. 


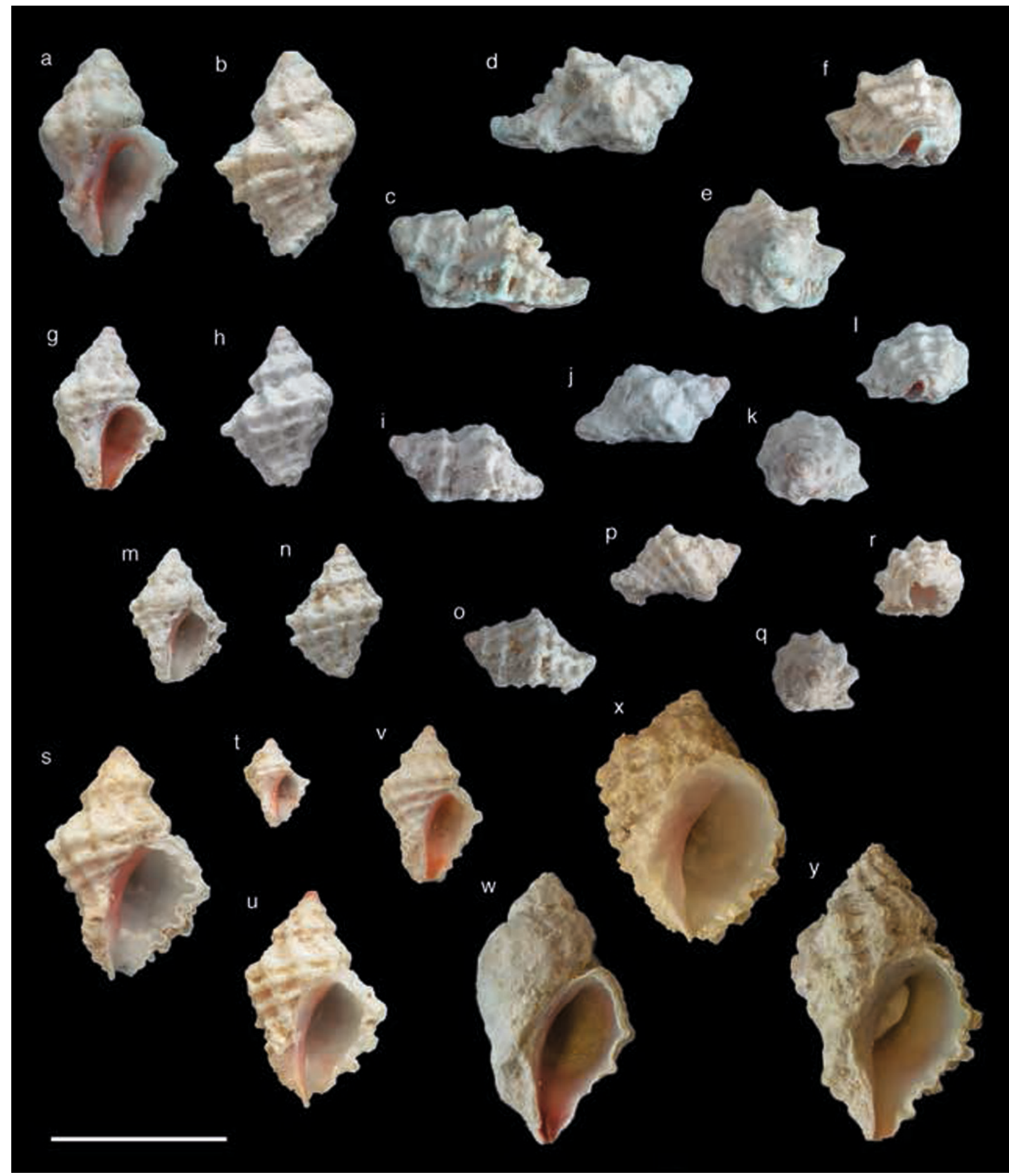

Fig. 20. Coralliophila curacaoensis sp. nov. Different views of shells of holotype RMNH.5004326 (a-f) and paratypes RMNH.5004327 (g-l) and RMNH.5004328 (m-r), as well as the ventral side of shells of paratypes RMNH.5004329 (s), RMNH.5004332 (t), RMNH.5004330 (u), RMNH.5004331 (v), RMNH.5004324 (w), RMNH.5004325 (x) and RMNH.5004323 (y). Some shells are photographed in a slightly different orientation (w-y). Scale bar: $1 \mathrm{~cm}$. 
of the total shell length, basal outline sharply curving at the shoulder, anterior to the shoulder straight, in some specimens more inflated. Aperture long, oval. Outer lip fimbriated; inner lip gently arcuate. Siphon canal broadly open, relatively long at around one fifth of the total shell length; umbilical area moderately wide, fasciole imbricate, umbilical furrow narrowly open.

Teleoconch sculptured with widely set spiral cords. Two high spiral cords on the body whorl, the first one located at the shoulder, the second directly anterior, widely spaced. Several, also widely spaced, smaller cords anterior to the two large cords (three on the holotype), decreasing in size. Spiral cords with relatively large imbricated scales, clearest at the intersection between varices and spiral cords. On the holotype, five small cords posterior to the shoulder on the body whorl, more closely set compared to cords anterior to the shoulder. Eight to nine varices per whorl, three of which very large on the body whorl of the holotype.

Shell colour ivory white. Operculum transparent to pale red.

Remarks. Among its Caribbean congeners, C. curacaoensis sp. nov. is the smallest species. It has only been found in association with M.auretenra. The mitochondrial marker $12 \mathrm{~S}$ rRNA of $C$. curacaoensis differs at on average $17.1 \%$ of positions from $C$. caribaea and $18.6 \%$ of positions from C. galea. For the COI marker, $24.6 \%$ of positions are on average different in C. caribaea compared to $C$. curacaoensis, and $21.9 \%$ of positions compared to C. galea.

Coralliophila curacaoensis sp. nov. resembles most C. caribaea, but it differs from that species in that the spiral cords on the body whorl are smaller on C. curacaoensis and more numerous and closely set on $C$. caribaea. Consequently, C. caribaea lacks the strongly fimbriated outer lip of $C$. curacaoensis. The colour of the operculum of $C$. caribaea is a deeper red than the operculum of $C$. curacaoensis. Sutures are generally less incised in C. caribaea.

Coralliophila galea, differs mainly from C. curacaoensis sp. nov. in having a more globose shell, having more numerous, closely set, spiral cords, lacking the high spiral cords and a fimbriated outer lip. The spire of C. galea is shorter and sutures are not incised as in $C$. curacaoensis.

Several other species of the genus Coralliophila are known from the western Atlantic, two of which resemble C. curacaoensis sp. nov.: C. pacei Petuch, 1987 and C. richardi (Fischer, 1882). Coralliophila pacei has only been found in shallow water along the southeastern coast of Florida (Petuch and Myers, 2014). It shows two large spiral cords on the body whorl, with two small cords in between, which are absent in C. curacaoensis. The large cords on C. curacaoensis are more widely spaced, decreasing in size anterior to the large cords. Furthermore, varices on C. curacaoensis are not as low as on C.pacei.

Coralliophila richardi is a deep-water species found on cold-water reefs formed by the scleractinians Lophelia pertusa (Linnaeus, 1758) and Madrepora oculata Linnaeus, 1758, across the North Atlantic (Bouchet and Warén 1985; Oliverio and Gofas, 2006; Schembri et al., 2007; Taviani et al., 2008, 2009). Coralliophila richardi lacks the high, imbricate spiral cords and therefore the fimbriated outer lip, which are shown by $C$. curacaoensis.

Coralliophila fontanangioyae Smriglio and Mariottini, 2000 is known from the Canary Islands in the Eastern Atlantic. It is relatively closely related but genetically distinct from $C$. curacaoensis sp. nov. (Fig. 15). Oliverio et al. (2009) published a $12 \mathrm{~S}$ rRNA sequence from $C$. fontanangioyae, which differs on average at $21.1 \%$ of positions from the newly sequenced $12 \mathrm{~S}$ rRNA sequences of $C$. curacaoensis. Morphologically, C. fontanangioyae resembles $C$. curacaoensis in shell ornamentation but its whorls have less sharper edges than those of $C$. curacaoenis (Gofas, 2005). Coralliophila fontanangioyae occurs in association with the deep-water scleractinian Madracis asperula Milne Edwards and Haime, 1849 (Smriglio and Mariottini, 2000; Oliverio et al., 2009), whereas C. curacaoenis and $C$. galea, have been found in association with colonies of Madracis auretenra.

Coralliophila meyendorffii (Calcara, 1845), the sister species of $C$. fontanangioyae (Fig. 15), has a much finer ornamentation and its spirals have edges that are less sharp than those of $C$. curacaoenis sp. nov. (see Oliverio and Gofas, 2006). It has an East Atlantic Mediterranean distribution over a wide depth range that includes the Adriatic Sea (Oliverio and Mariottini, 2001; Oliverio and Gofas, 2006; Kružić et al., 2013). It predates on the scleractinians Balanophyllia europaea (Risso, 1826) or Cladocora caespitosa (Linnaeus, 1767) (Oliverio and Mariottini, 2001b; Kružić et al., 2013), while it is also known as an associate of sea anemones (Oliverio and Mariottini, 2001b; Oliverio and Gofas, 2006).

Other East Atlantic Coralliophila species are predominantly known from deep water and have not been recorded from the West Atlantic and not as associates of either scleractinians or alcyonaceans (Pons-Moyà et al. 2001; Oliverio and Gofas, 2006; Oliverio et al., 2009). 


\section{Supplementary methods 1}

\section{Replication error in morphological data}

To test the robustness of landmark data and shell length measurements and calculate the error of landmark data arising from parallax or encrusting algae (obscuring landmark location), a random selection of shells ( $\sim 10 \%$ of specimens) was measured and photographed in triplicate, in three different sessions, and landmarks on each of the three replicate images of a shell were recorded in triplicate, again in three different sessions. The three-way interaction between these three factors (individual shells, three photos per shell, three replicate sets of landmarks per photo) was tested in a Procrustes ANOVA. Mean of squares of the different terms in the ANOVA were used to calculate error by using the following equation (Adams et al., 2015):

$$
1-\frac{\frac{M S_{\text {stell }}-M S_{x}}{n}}{M S_{x}+\frac{M S_{\text {stell }}-M S_{x}}{n}}
$$

In equation $1, M S_{\text {shell }}$ is the mean of squares of the factor shell in the ANOVA model, $M S_{x}$ is the mean of squares of either the three-way interaction between the factors shell, photo and digitizing replicate (to calculate the digitizing error, i.e. the repeatability of landmarks) or the interaction between the factors shell and photo, to calculate the total error (also including the digitizing error). The number of replicates (in both these cases three) is represented by $n$. Errors were calculated separately for different species.

\section{Reference}

Adams DC, Collyer ML, Sherrat E. 2015. Geomorph: Software for geometric morphometric analyses. R package version 2.1.5. Available at: https://cran.r-project.org/web/packages/geomorph/index.html. 


\section{Supplementary methods 2}

\section{Allometric patterns}

Allometric patterns among groups of snail were assessed using the vectors of shell length. Patterns were compared on two distinct points. Firstly, the distance among shell length vectors was calculated. This distance corresponds to the amount of change in shell shape per unit of shell growth. Secondly, the correlation among shell length vectors was calculated. The correlation among vectors is related to the direction of change in shell shape with increasing shell length. A low correlation among vectors represents a difference in direction of change.

As an example, consider three groups of hypothetical snails characterized by different allometric patterns (see figure). While at small sizes (e.g., a shell length of $5 \mathrm{~mm}$ ), the shell shapes are indistinguishable among groups, larger shells (e.g., a shell length of $15 \mathrm{~mm}$ ) have different shapes because of differences in the allometric patterns. Red and blue snails differ in the distance between shell length vectors. With increasing shell length, both follow the same path in the principal component plot. The correlation between vectors is therefore high, and the direction of shell shape change does not differ between the blue and red snails. However, compared to the red snails, the shell shape of blue snails changes more with an equal increase in shell length. The amount of change per unit of growth in shell length differs therefore between the red and blue snails, which is reflected in the distance between shell length vectors. The allometric pattern of the third group of snails differs from both the blue and red snails in the direction of change in shell shape. In the principal component space, the yellow snails follow a different path than the blue and yellow snails. Besides a large distance among vectors (i.e., the amount of change per unit of growth differs between the yellow and both red and blue snails), the correlation between the shell length vector of the yellow snails on one hand and the blue and red snails on the other hand is therefore low, signifying a difference in direction of shell shape change with growth.

All morphometric analyses were done in R, using the package Geomorph 2.1.5 (Adams and Otárola-Castillo, 2013; Adams et al., 2015; R Core Team, 2015).

\section{References}

Adams DC, Otárola-Castillo E. 2013. Geomorph: an R package for the collection and analysis of geometric morphometric shape data. Methods in Ecology and Evolution 4: 393-399.

Adams DC, Collyer ML, Sherrat E. 2015. geomorph: Software for geometric morphometric analyses. R package version 2.1.5. Available at: https://cran.r-project.org/web/packages/geomorph/index.html.

R Core Team. 2015. R: A language and environment for statistical computing. 


\section{Supplementary table $S 1$}

Table S1. GenBank accession numbers of additional, previously published cytochrome $c$ oxidase subunit I (COI) sequences of the used in the Automatic Barcode Gap Discovery (ABGD) analysis, with the references to the original publication. All sequences belong to species of the muricid subfamily Coralliophilinae.

\begin{tabular}{|c|c|c|}
\hline Species & GenBank accession numbers & References $^{\mathrm{a}}$ \\
\hline Babelomurex cariniferus & FN651934 & 1 \\
\hline Babelomurex spinosus & FN651935 & 1 \\
\hline Coralliophila erosa & FR853815 & 2 \\
\hline Coralliophila galea $^{\mathrm{b}}$ & U86331 & 3 \\
\hline Coralliophila meyendorffii & EU870569, FN651936 & 4,1 \\
\hline Coralliophila mira & FN651937 & 1 \\
\hline Coralliophila monodonta ${ }^{\mathrm{c}}$ & FN651940 & 1 \\
\hline Coralliophila violacea & FR853816 & 2 \\
\hline Latiaxis pilsbryi & FN651938 & 1 \\
\hline Leptoconchus inactiniformis & EU215826 & 5 \\
\hline Leptoconchus inalbechi & EU215802, EU215803, EU215806-EU215808 & 5 \\
\hline Leptoconchus incrassa & EU215804, EU215805 & 5 \\
\hline Leptoconchus incycloseris & EU215812-EU215816, EU215861 & 5 \\
\hline Leptoconchus infungites & EU215817-EU215820 & 5 \\
\hline Leptoconchus ingrandifungi & EU215839, EU215843, EU215844, EU215852, EU215864, EU215865 & 5 \\
\hline Leptoconchus ingranulosa & EU215821-EU215823 & 5 \\
\hline Leptoconchus inlimax & EU215829-EU215833 & 5 \\
\hline Leptoconchus inpileus & EU215840-EU215842 & 5 \\
\hline Leptoconchus inpleuractis & EU215834-EU215838 & 5 \\
\hline Leptoconchus inscruposa & EU215854-EU215855 & 5 \\
\hline Leptoconchus inscutaria & EU215857-EU215859 & 5 \\
\hline Leptoconchus intalpina & EU215845-EU215847, EU215860 & 5 \\
\hline Leptoconchus massini & EU215809-EU215811, EU215827, EU215848-EU215851, EU215853 & 5 \\
\hline Leptoconchus vangoethemi & EU215828, EU215862, EU215863 & 5 \\
\hline Leptoconchus sp. & FN651939 & 1 \\
\hline Rapa rapa & FN651941 & 1 \\
\hline \multicolumn{2}{|c|}{$\begin{array}{l}\text { a: 1: Barco et al., 2010; 2: Claremont et al., 2011; 3: Harasewych et al., 1997; 4: Puillandre et al., 2009; 5: Gittenberger } \\
\text { and Gittenberger, } 2011\end{array}$} & Gittenberger \\
\hline
\end{tabular}

\section{References}

Barco A, Claremont M, Reid DG, Houart R, Bouchet P, Williams ST, Cruaud C, Couloux A, Oliverio M. 2010. A molecular phylogenetic framework for the Muricidae, a diverse family of carnivorous gastropods. Molecular Phylogenetics and Evolution 56: 1025-1039.

Claremont M, Reid DG, Williams ST. 2011. Evolution of corallivory in the gastropod genus Drupella. Coral Reefs 30: 977-990.

Gittenberger A, Gittenberger E. 2011. Cryptic, adaptive radiation of endoparasitic snails: Sibling species of Leptoconchus (Gastropoda: Coralliophilidae) in corals. Organisms Diversity and Evolution 11: 21-41.

Harasewych MG, Adamkewicz SL, Blake JA, Saudek D, Spriggs T, Bult CJ. Neogastropod phylogeny: a molecular perspective. Journal of Molluscan Studies 63: 327-351.

Puillandre N, Strong EE, Bouchet P, Boisselier M-C, Couloux A, Samadi S. 2009. Identifying gastropod spawn from DNA barcodes: Possible but not yet practicable. Molecular Ecology Resources 9: 1311-1321. 


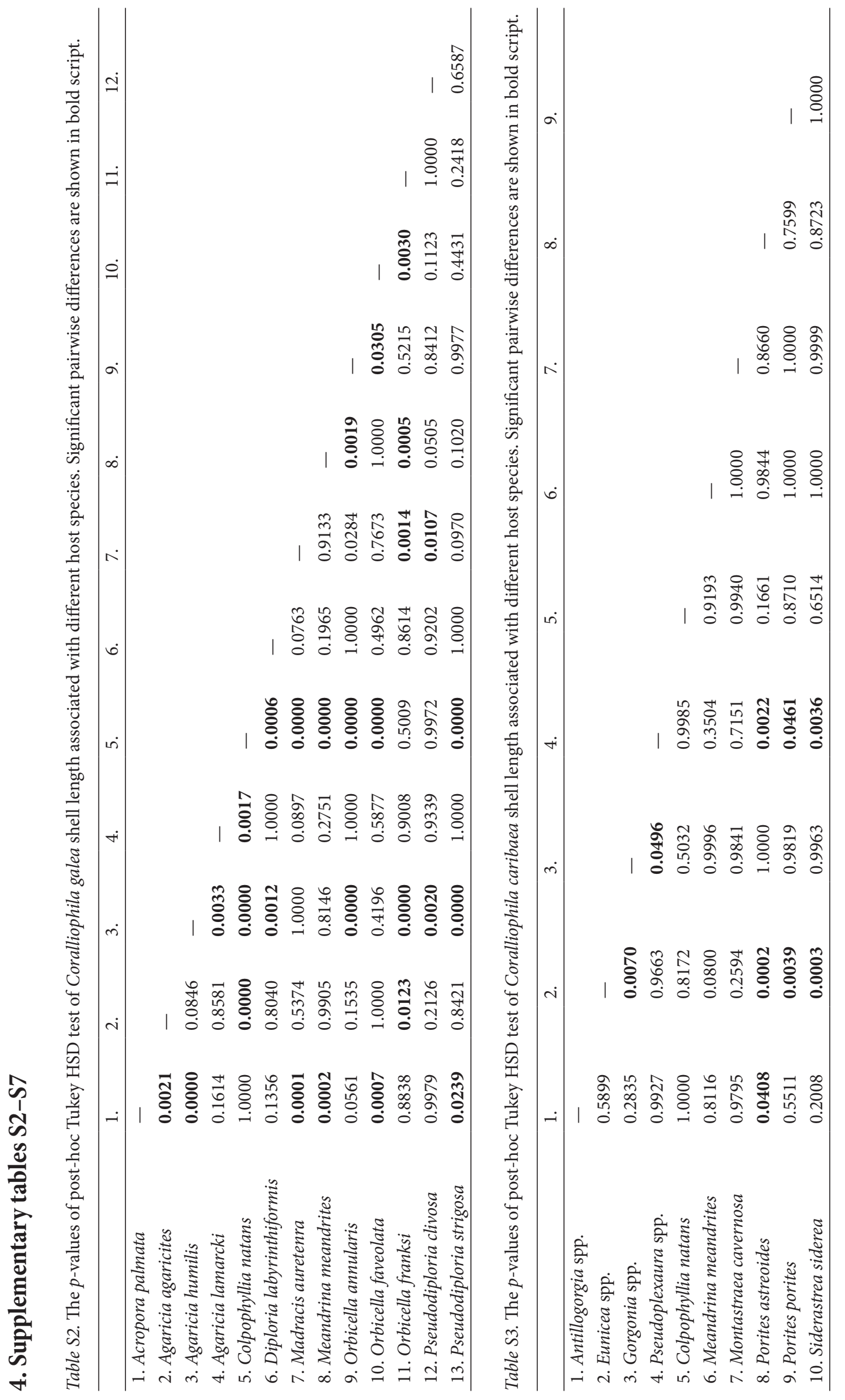




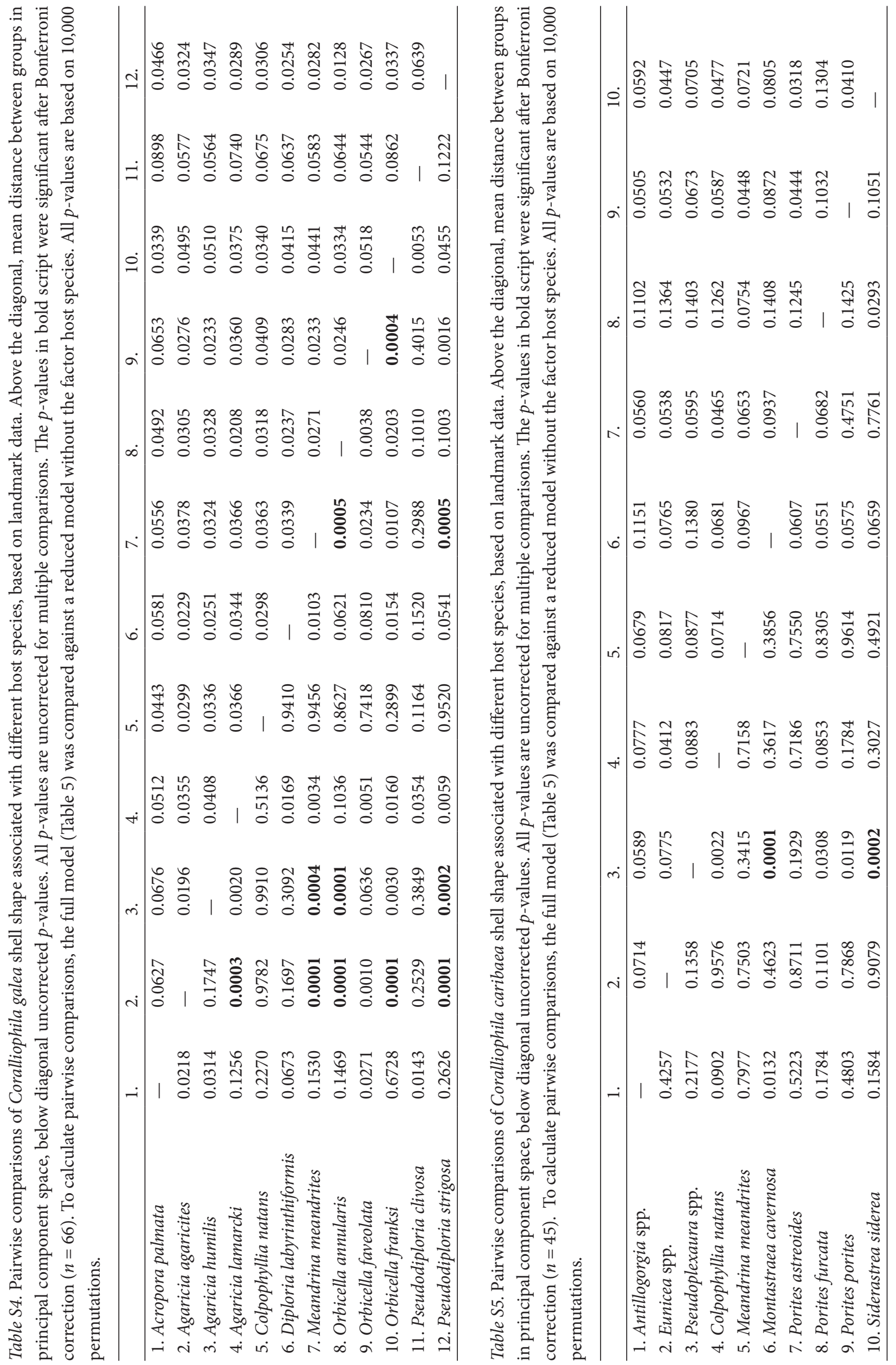




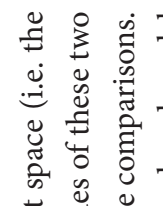

कै 苛苛

苦言青

हี जี

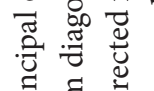

范

$\Xi$ 용

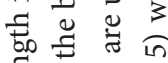

可苛

矛薜

प्ष

记

过

जี

总芯

प

苞 :

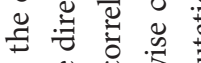

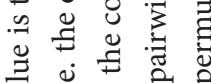

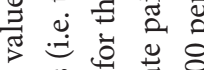

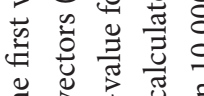

ॠ

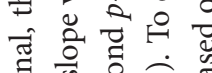

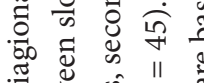

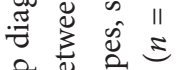

के

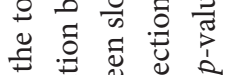

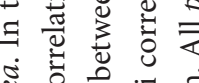

ธัँ

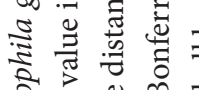

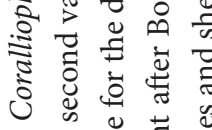

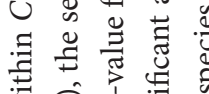

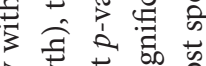

言言总悹

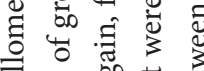

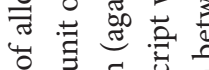

政

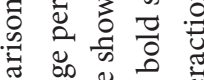

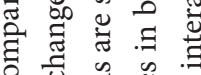

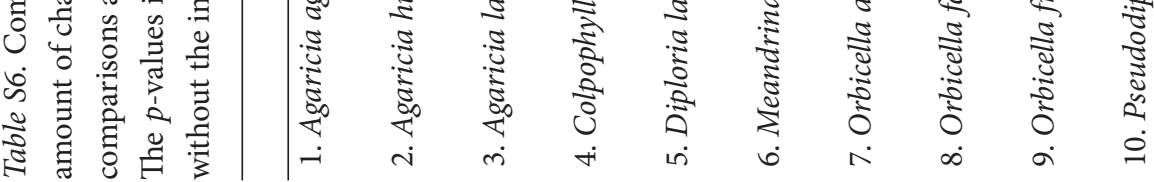

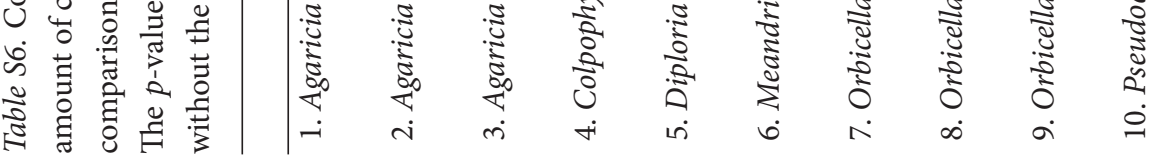

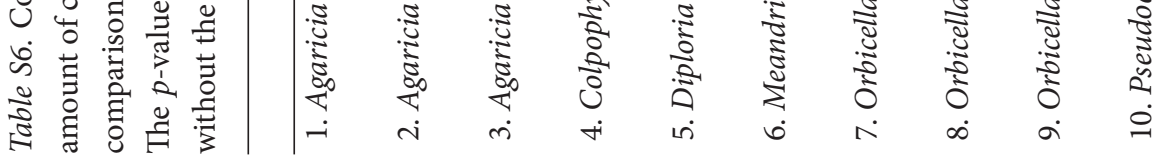

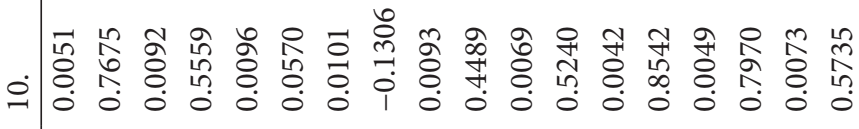

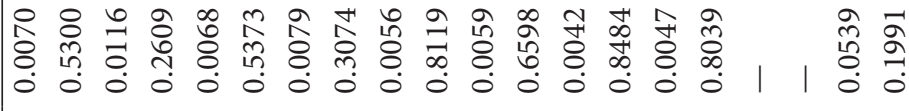

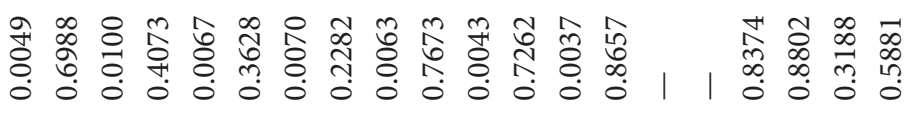

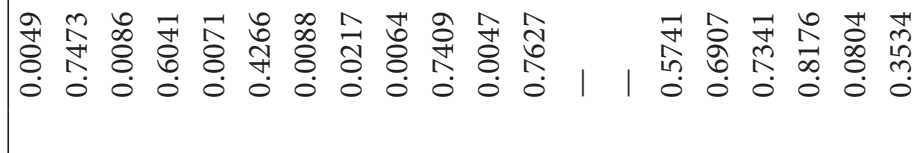

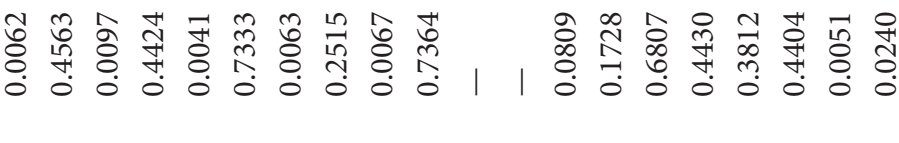

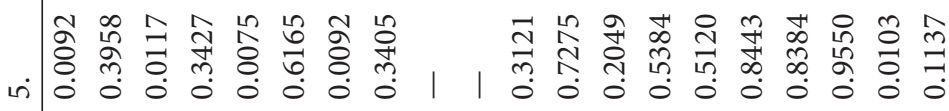

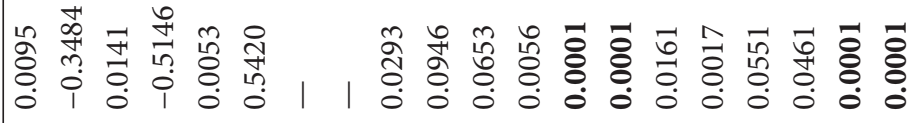

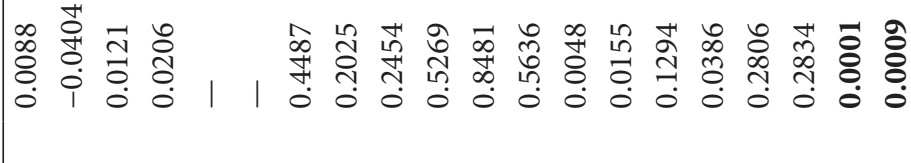

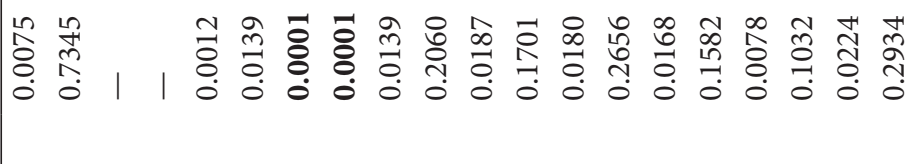

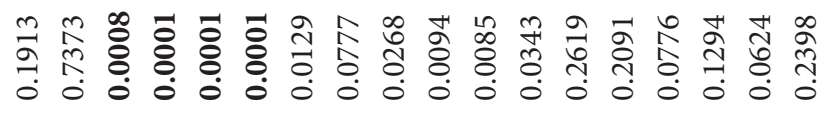


Table S7. Comparison of allometry within Coralliophila caribaea. In the top diagional, the first value is the distance between slopes of shell length in principal component space (i.e. the amount of change per unit of growth), the second value is correlation between slope vectors (i.e. the direction of change in shell length). In the bottom diagonal, $p$-values of these two comparisons are shown (again, first $p$-value for the distance between slopes, second $p$-value for the correlation between slopes). All $p$-values are uncorrected for multiple comparisons. The $p$-values in bold script were significant after Bonferroni correction $(n=3)$. To calculate pairwise comparisons, the full model (Table 5 ) was compared against a reduced model without the interaction between host species and shell length. All $p$-values are based on 10,000 permutations.

\begin{tabular}{llll}
\hline & 1. & 2. & 3. \\
\hline 1. Pseudoplexaura spp. & - & 0.0110 & 0.0087 \\
& - & 0.4419 & -0.3287 \\
2. Porites porites & 0.4658 & - & 0.0123 \\
& 0.7390 & - & 0.1877 \\
3. Siderastrea siderea & 0.2943 & 0.1155 & - \\
& $\mathbf{0 . 0 1 6 5}$ & 0.2387 & - \\
\hline
\end{tabular}




\section{Supplementary figures S1-S2}

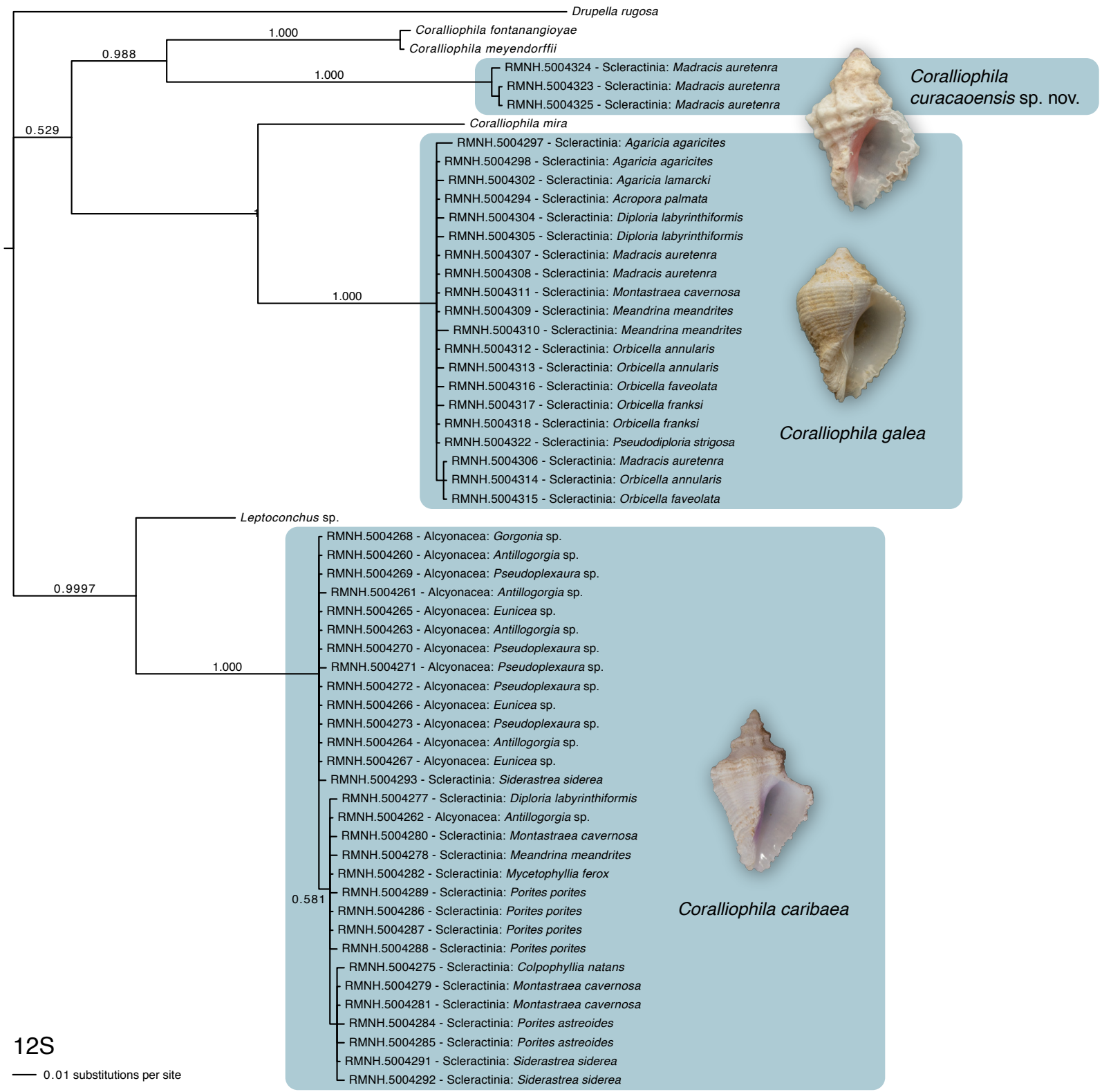

Fig. S1. Phylogenetic tree based on the 12S rRNA (12S) marker of a selection of the collected Coralliophila spp. specimens. The three shaded clades represent the three species of Coralliophila found in the present study. Within the shaded clusters, tip labels represent the host order and host species with which the snail was associated. Specimens outside the shaded cluster are previously published sequences. Branch labels are posterior probabilities (PP). Intraspecific PP-values are not shown (except for the main clade within C. caribaea). Scale bar: 0.01 substitutions per site. 


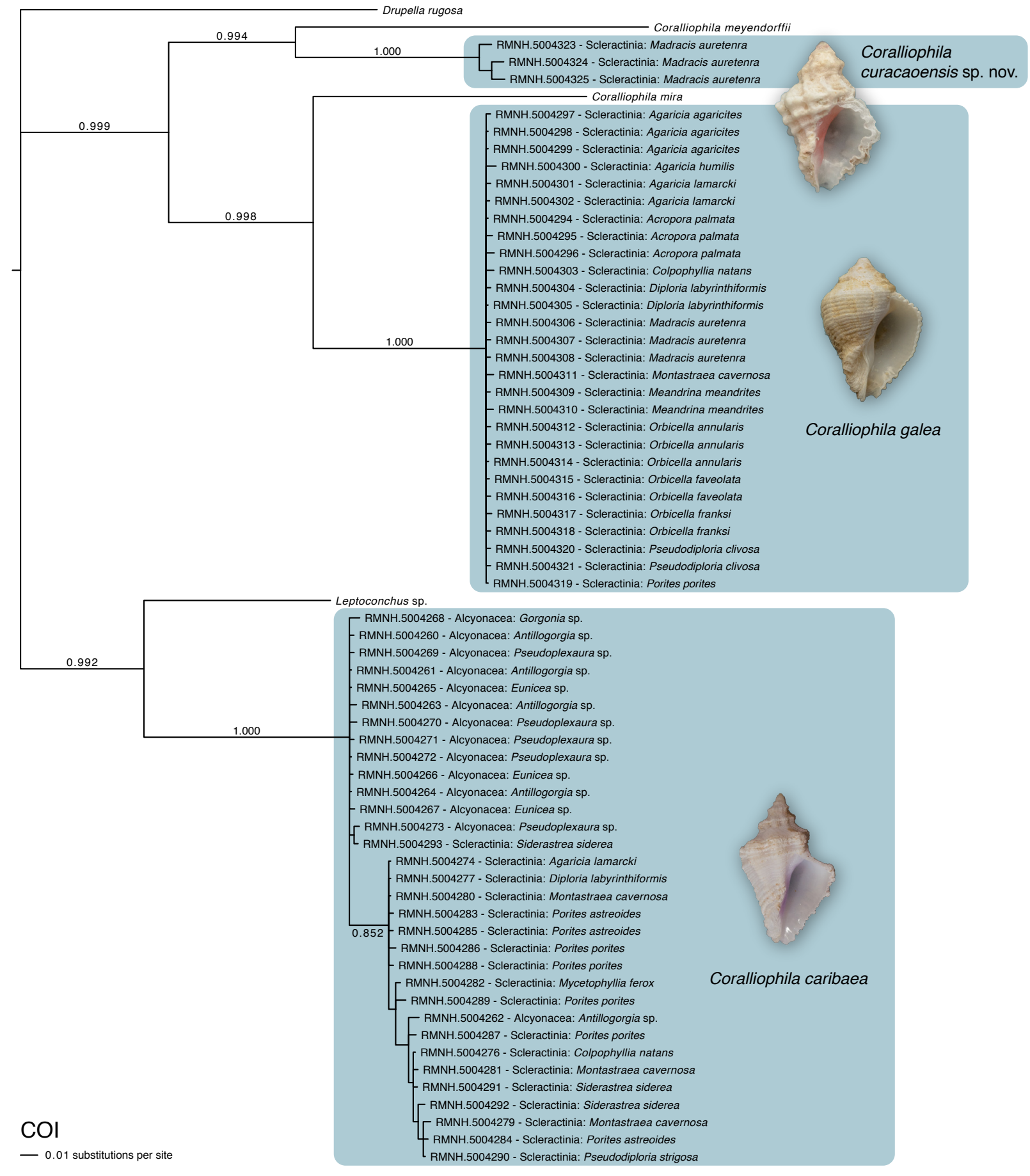

Fig. S2. Phylogenetic tree based on the cytochrome $c$ oxidase subunit I (COI) marker of a selection of the collected Coralliophila spp. specimens. The three shaded clades represent the three species of Coralliophila found in the present study. Within the shaded clusters, tip labels represent the host order and host species with which the snail was associated. Specimens outside the shaded cluster are previously published sequences. Branch labels are posterior probabilities (PP). Intraspecific PP-values are not shown (except for the main clade within C. caribaea). Scale bar: 0.01 substitutions per site. 